\title{
نطاق الصورية
}

الباحث/ عماد هممد هسن القنيشي 


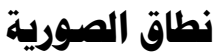

\section{الباحث/ عماد هممد حسن القنيشي}

المقدهة

تمثل موضوعات نظرية الالتزام أهمية كبرى لباحثي القانون الخاص ودارسيه، إذ إذ الذارئ

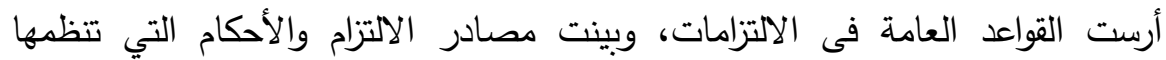

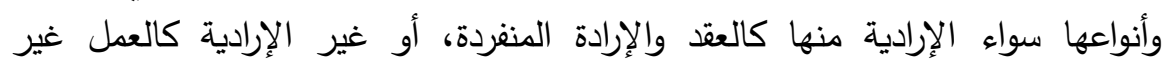

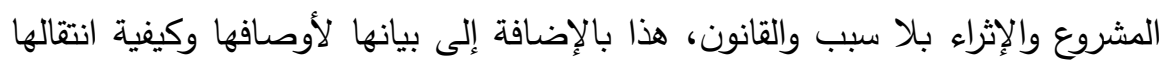
والوفاء بها وانتضائها. والعقد باعتباره أحد مصادر الالتزام يعتبر من الوسائل المهمة التي يمكن للفرد

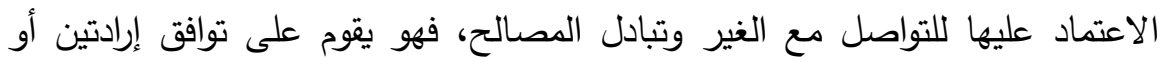

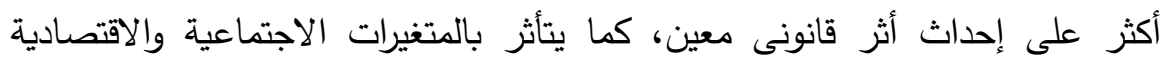

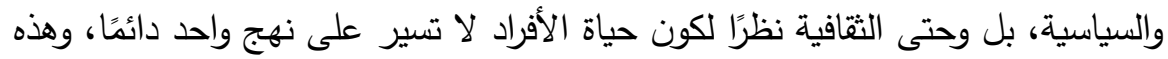
المتغيرات قد أسهمت بثكل ملحوظ فى بلورة القواعد التي تحكم النظام القانونى للعقد

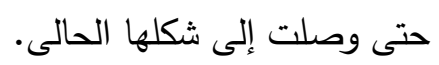
والأصل العام فى العقود أنها تؤسس على مبدأ الرضائية، فالتراضى وحده هو الذي وتئي

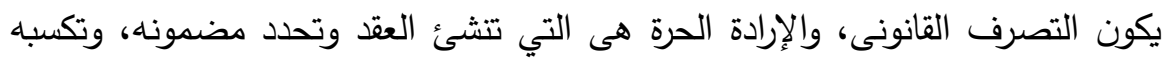

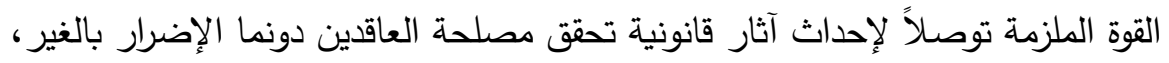

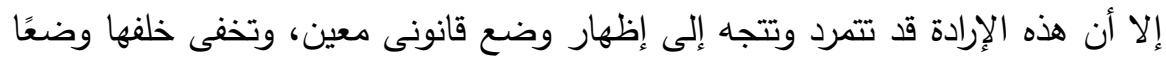

$$
\text { آخر وهو ما يعرف بالصورية. }
$$

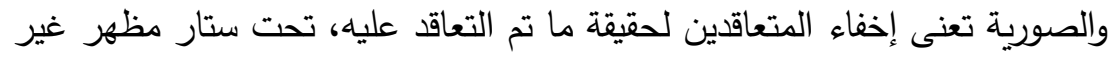

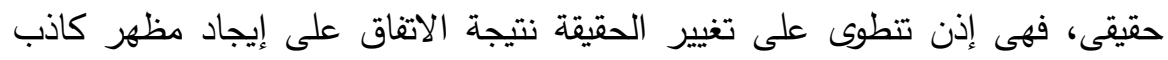

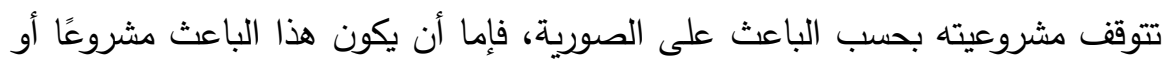

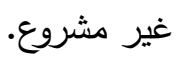

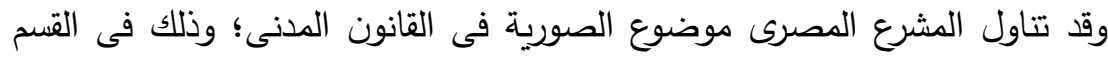

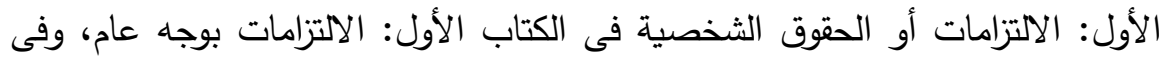

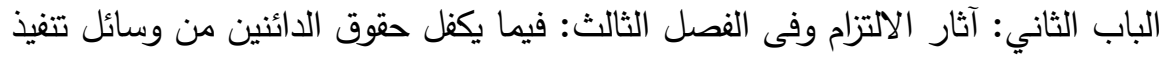

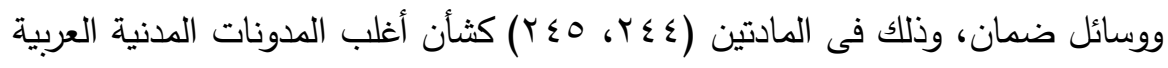
والفقه المدنى الذي تتاول موضوع الصورية فى استعراضه لأحكام الالتزام فى القانون

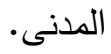


الباحث/ عماد محمد حسن القتيشي

\section{المبحث الأول \\ نطاق الصورية}

المقصود بنطاق الصورية هو المجالات التي تعمل فيها الصورية؛ ونظرًا لتشعب

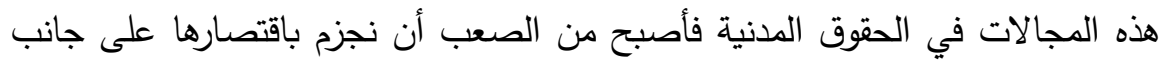

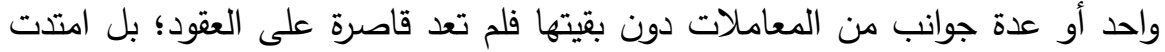

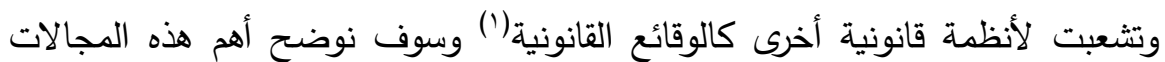

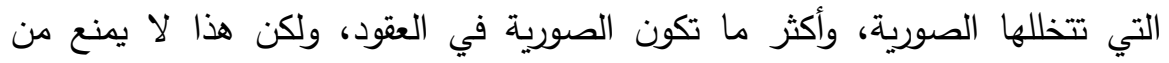

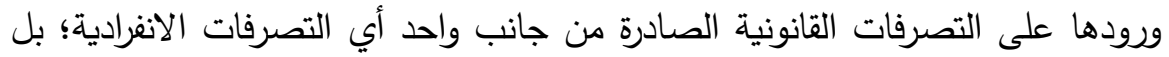

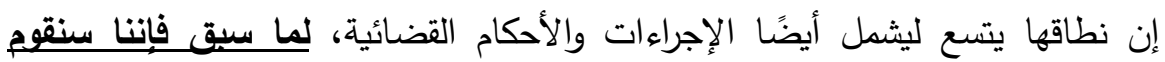
بتقسيم هذا المبحث على النحو الآتي: لئي المطلب الأول:- الصورية في العقود الرسمية والعقود العرفية. الفرع الأول:- الصورية في العقود الرسمية. الفرع الثاني:- الصورية في العقود العرفية. المطلب الثاني:- الصورية في التصرفات الانفرادية. المطلب الثالث:- الصورية في الدعاوى والإجراءات والأحكام القضائية وأحكام رسو

$$
\text { الفرع الثاني:- الصورية في الأول - الصورية في الدعاوى والإجراءات والأحكام القضائية. }
$$

الصورية في العقود الرسمية والعقود العرفية العية

لما كانت العقود هي أكثر التصرفات التي ترد عليها الصورية؛ فهي مجالها الخصب، فما من عقد من العقود المتعلقة بالذمة المالية سواء أكان منشئًا أم ناقلاً أم الم المان مسقطًا إلا ويرد عليه الصورية.

\section{الفرع الأول}

\section{الصورية في العقود الرسميمية}

أورد القانون المدني المصري في المادة ( • () من قانون الإثبات أن "المحررات

الرسمية هي التي يثبت فيها موظف عام أو شخص مكلف بخدمة عامة ما تم على في

$$
\text { (') (') مجدى حسن خليل، الصورية، رسالته السابقة، ص .0. }
$$

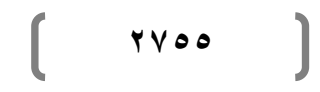


يديه، أو ما تلقاه من ذوى الثأن وذلك طبقًا للأوضاع القانونية، وفى حدود سلطته واختصاصه.....إلخ"(r).

(ז) المحرر الرسمي أو الورقة الرسمية هي كل ورقة صادرة من موظف عام أو شخص مكلف بخدمة عمومية مختص بتحريرها من حيث نوعها ومن حيث مكان التحرير حسب القواعد المقررة قانونًا يثبت ما

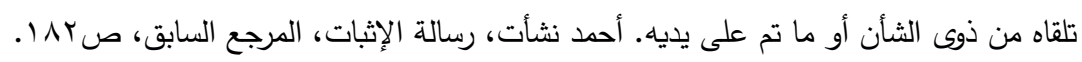
والأوراق الرسمية كثيرة ومتنوعة وقد تصدر عن السلطة التشريعية وقد تصدر عن السلطة التنفيذية وقد تصدر عن السلطة القضائية وقد تصدر في شكل قانون أو معاهدة أو تصدر في شكل حكم أو أمر ولائي أو تصدر في شكل لائحة أو تصدر لتثبت تصرفًا قانونيًا وقد يتطلب المشرع مجرد الرسمية وقد يتطلب فوق ذلك التسجيل أي القيد وقد يتطلب المشرع حسب الأحوال أن تتضمن المحررات الرسمية بيانات معينة بخلاف تلك البيانات العامة المقرة في المادة (• ( ) كما هو الحال بصدد صحيفة الدعوى أو الحكم الصادر فيها وقد تكون الورقة الرسمية سندًا تنفيذيًا، وقد لا تكون وبعبارة أخرى ليست كل ورقة رسمية بالمعنى المقصود في المادة العاشرة من قانون الإثبات سندًا قابلاً بذاته للتنفيذ ولو تضمنت إقرارًا بحق أو تعهدًا بشيء. أحمد أبو الوفا، التعليق عل نصوص قانون الاثبات مقدمة فى علم الاثبات،

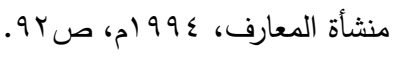
ويحب أن تتوافر ثلاثة شروط ليكتسب المحر صفة الرسمية وهى: الشرط الاول- صدور الورقة من موظف عام أو شخص مكلف بخدمة عامة حيث إن صفة الورقة الرسمية لا تثبيت الا للمحررات التي تصدر من موظف عام أو شخص ملف بخدمة عامة ويقصد بالموظف العام هو كل شخص عينته الدولة للقيام بعمل من اعمالها سواء أجرته لهذا العمل أو لم تؤجره

$$
\text { وسواء الحقته بالعمل في إحدى إدارتها الرئيسية كالوزارات أو في أي من المصالح. }
$$
الثرط الثاني- صدور الورقة من الموظف العام في حدود سلطته واختصاصة: أولاً- في حدود سلطته ويقصد بهذا الثرط أن يكون الموظف قد قام بتحرير الورقة أثناء ثبوت ولايته بمعنى أن يكون قائما بعمله قانونا وقت تحريرها أما اذا كان حررها بعد صدور قرار بنقله أو بوقفه أو عزله وإبلاغه بهذا القرار فإن ما يحرره لا يعتبر ورقة رسمية. أما إذا كان حررها في الفترة ما بين صدور القرار المذكور وإبلاغه به فإن الورقة تكون صحيحة إذا كان ذوو الثأن فيها حسني النية. ثانيا- في حدود اختصاصده ويقصد بهذا الشرط أن يكون الموظف مختصا نوعيا ومكانيا بتحرير الورقة ذلك إن كل نوع من الأوراق يتولى دونى تحريره نوع معين من الموظفين فإذا حررت الورقة من غير مختص نوعيًا بتحريرها لا تكون لها صفة إنة المحرر الرسمي ومن جهة أخرى فإن لكل موظف عام دائرة اختصاص مكاني لا تكون له من سلطة وظيفية في خارج نطاقها وقد نص قانون الإثبات على أنه لا يجوز للموثق أن يباشر عمله إلا في دائرة 
نطاق الصورية

الباحث/ عماد محمد حسن القتيشي

فالعقد يكتسب الصفة الرسمية بتدخل الموظف العام في تحريره سواء في بادئ

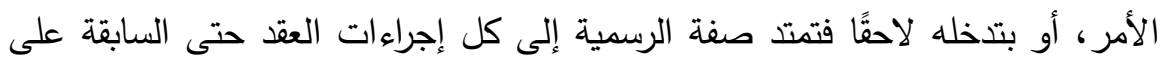

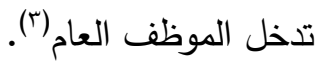

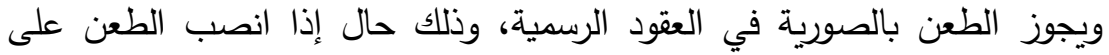

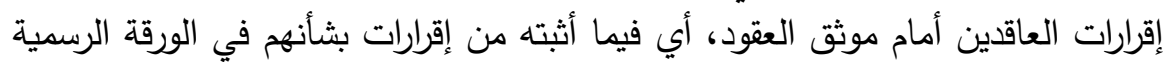

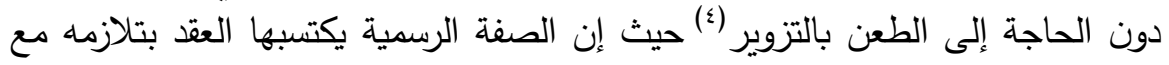
ما يثبته الموثق من الوقائع الحاصلة أمامه. فإقرار البائع بالبيع وقبض الثية الثمن من

الثرط الثالث- ضرورة مراعاة الأوضاع القانونية في تحرير الورقة حيث إن القانون يقرر لكل نوع من

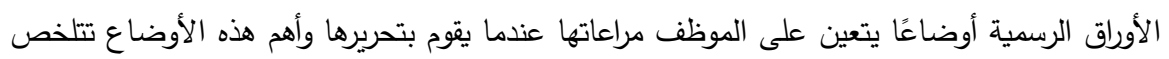

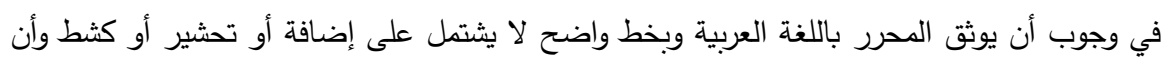

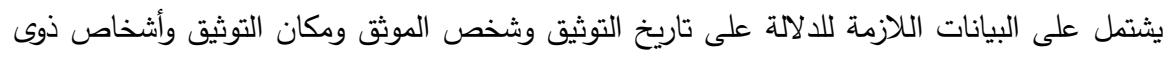

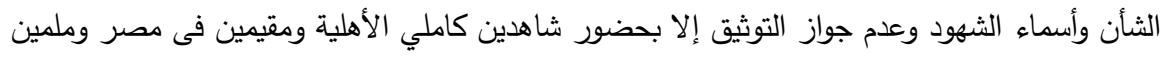

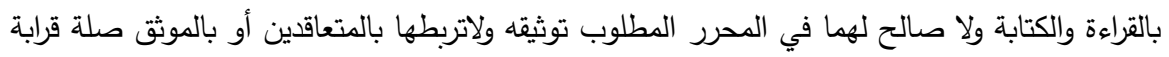

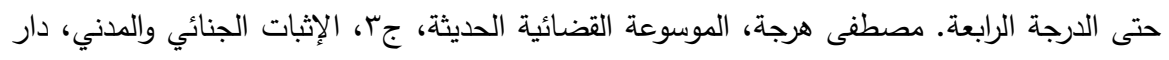

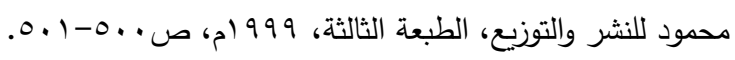
(r) حسام الدين كامل الأهوانى، شرح قانون الإثبات، دار النصر للطباعة الحديثة، الطبعة الثانية،

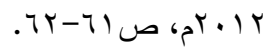

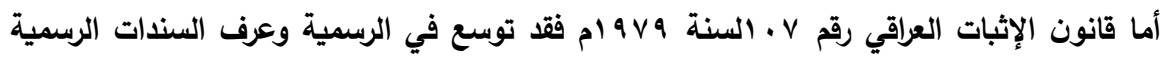

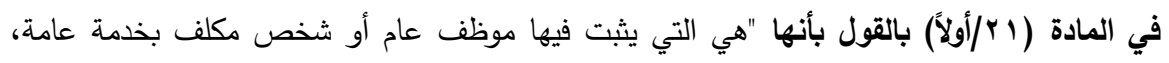

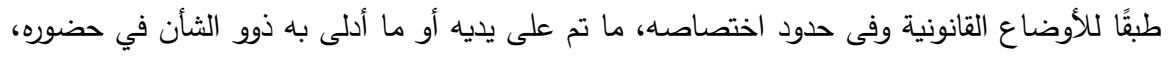

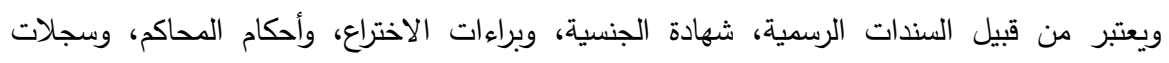

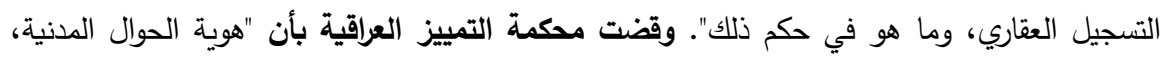

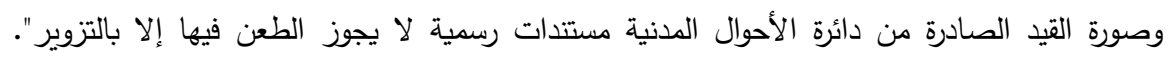

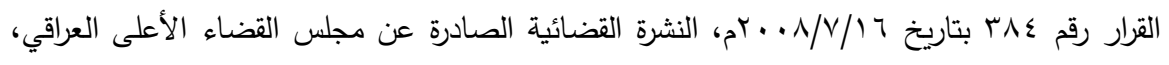

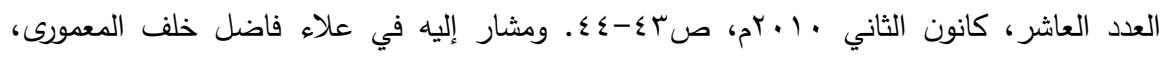

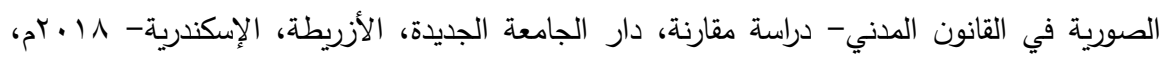

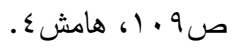
(\{) سليمان مرقص، شرح القانون المدني، ج)، مصادر الالتزام وآثاره، المطبعة العالمية، طبعة ع 9 ام، 
المشتري بالشراء لا يمنع من إثبات صورية كل ذلك بالطرق التي قررها القانون لإثبات

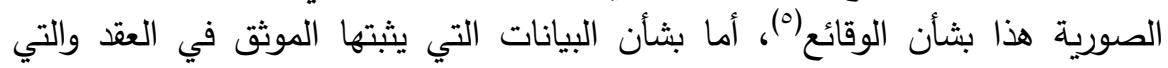

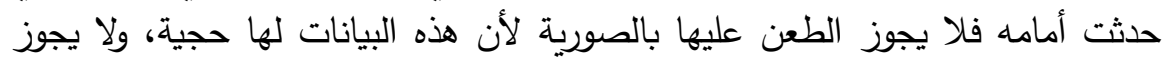

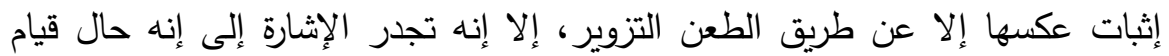

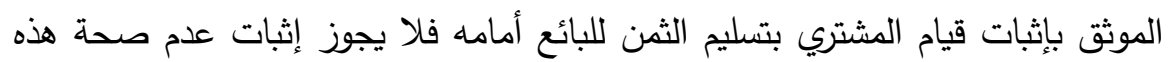

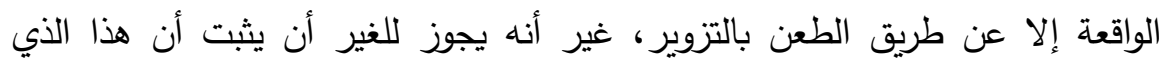

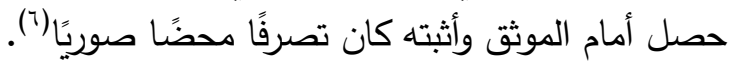

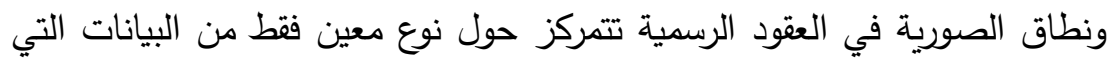

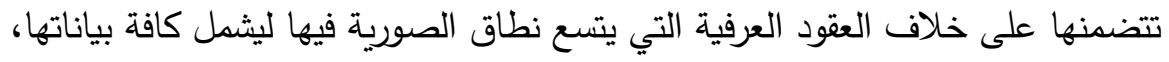

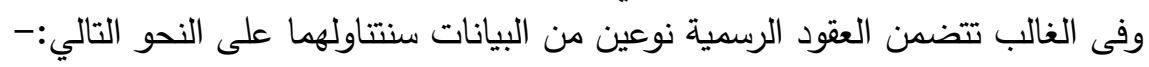

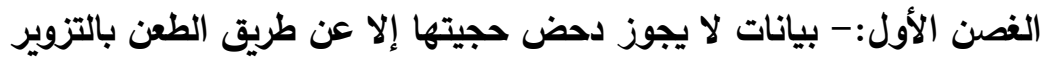

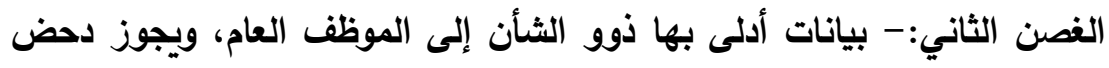

\section{حجيتها بإثبات العكس دون الطعن بالتزوير الغصن الأول}

بيانات لا يجوز دهض هميتها إلا عن طريق الاول الطعن بالتروير

وهى تلك البيانات التي تلقاها موظف عام لله سلطة توثيقها بالنسبة لطبيعتها، وقام

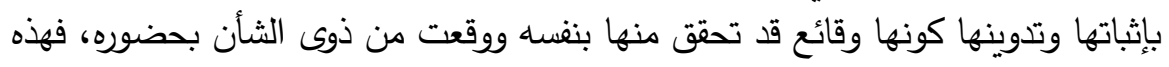

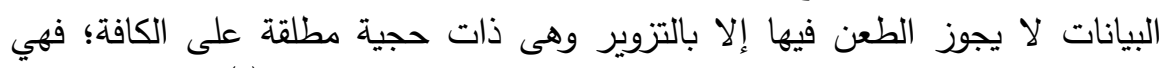

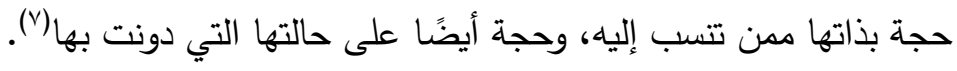

(०) أقرت محكمة التمييز الأردنية مبدأ إمكانية الطعن بالصورية في السندات الرسمية حيث قضت بأنه

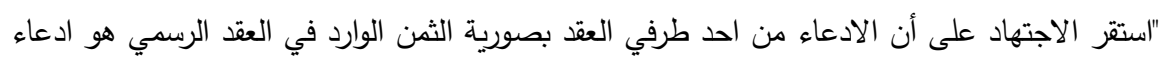

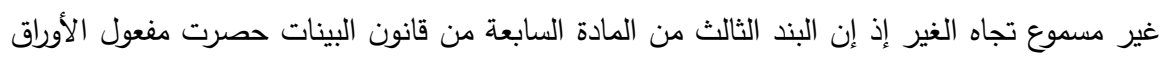

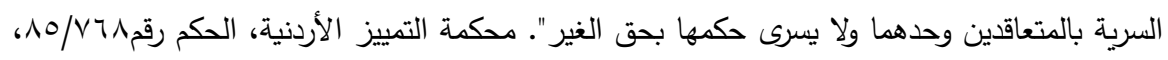

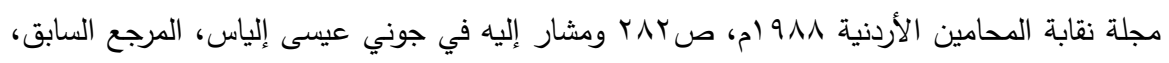

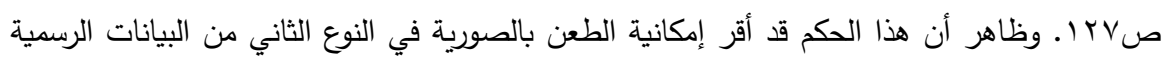

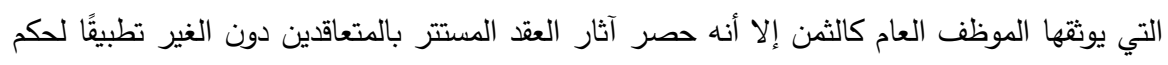

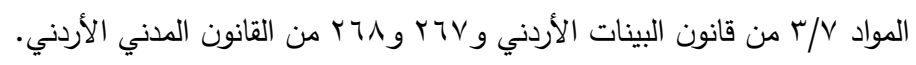

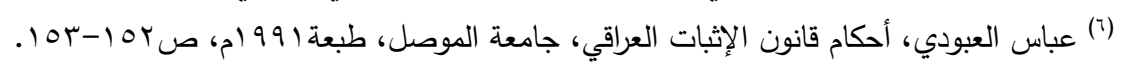

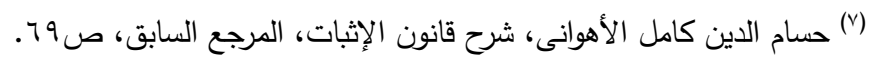

\section{$(r v \bullet \wedge)$}


فالموظف العام هو شخص حرص عليه المشرع وأحاط تعيينه ونشاطه بضمانات

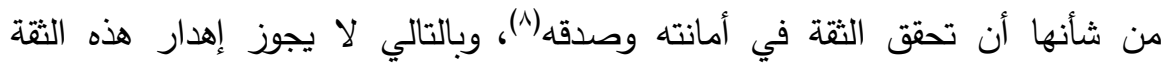

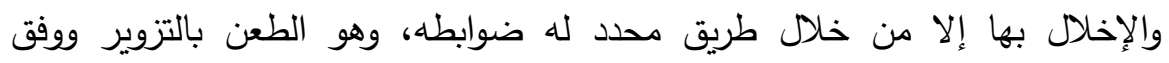
الإجراءات المحددة بهذا الثأن وليس كل هذا التثدد إلا محافظة على التقة التي أولاها المجتمع لهذا الموظف، ومن ثم فإن الطعن على هذه البيانات بالصورية يصبح غير لهن جديرًا بالقبول (9). ومن أمثلة هذه البيانات التي تصدر عن الموظف العام بذاته، كتابة المحرر الرسمي

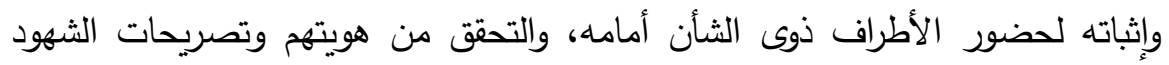
وتواريخ كتابة العقود ومكان توقيعها، وتوقيع الأطراف على العقود والإقرارات المقدمة دونة

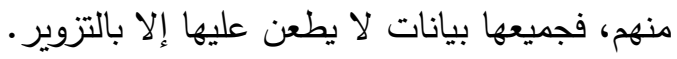

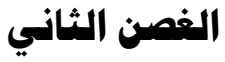

بيانات أدلى بها ذوو الثأن إلى الموظف العام ويجمز دهض حبيتها بإثبات

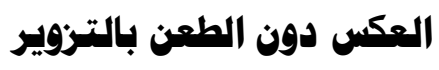

وهذه البيانات قام ذوو الثأن بالإدلاء بها إلى الموظف العام فقام بتدوينها تحت

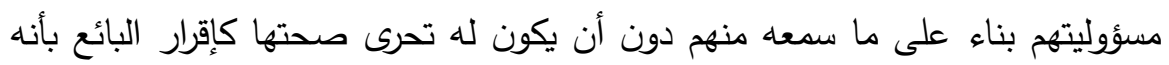

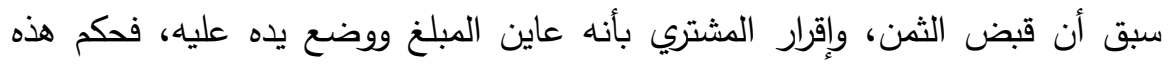

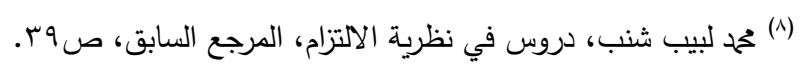

(9) لا يعتبر بمثابة مثلب على هذا القول ما أجمع عليه الفقهاء من أن العقد الرسمي المتضمن لفئل الفوائد

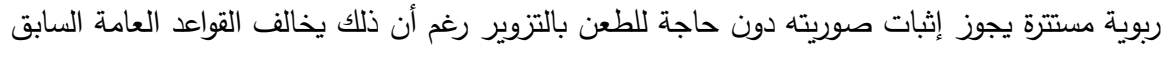

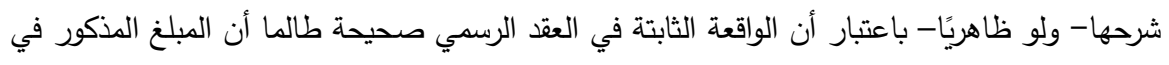

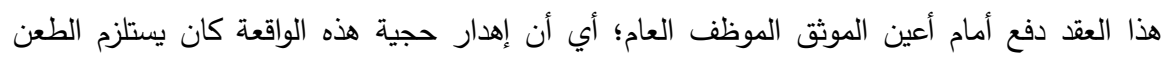

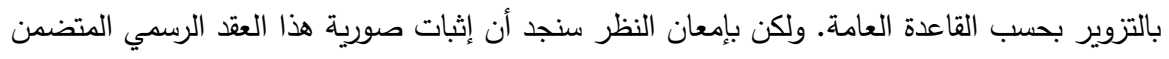

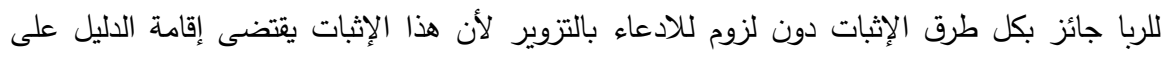

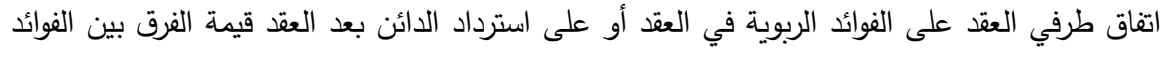

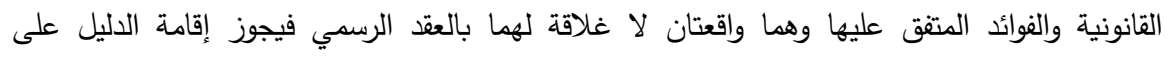

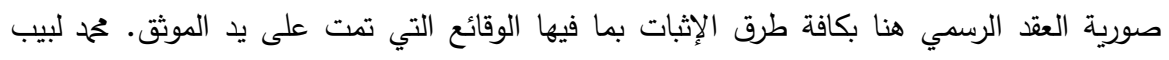

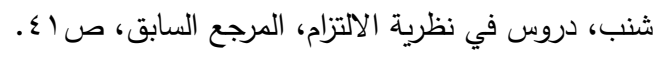

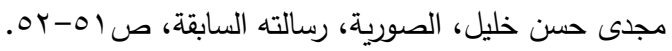

\section{(rvoq)}


البيانات فيما يتعلق بصحة مضمونها- لا فيما يتعلق بواقعة تقريرها لا يختلف عن حكم البيانات الواردة في ورقة عرفية(·'). ونظرًا لأن دحض حجية هذه البيانات لا تمس بأمانة الموثق وصدقة وقدة، فقد أجاز

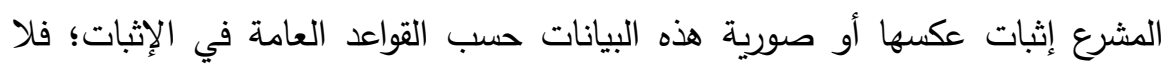

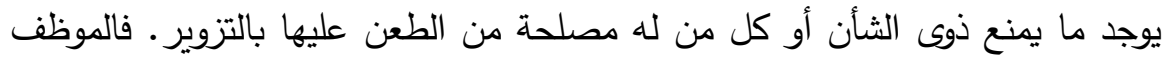

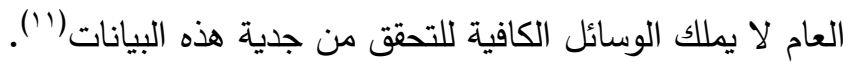

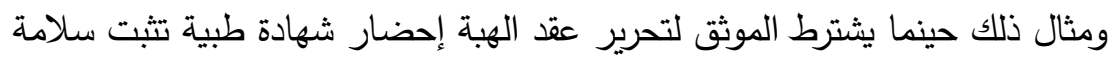
الواهب واكتمال لقواه العقلية؛ فإذا ظهر فيما بعد أنه مختل عقلئًا أو فاقدًا للأهلية فإن إندان

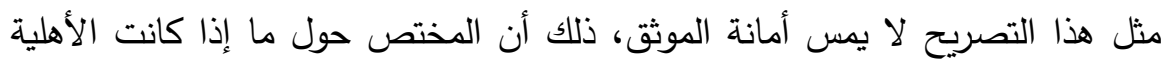

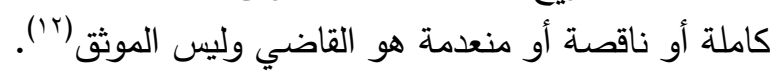
إلا إنه لا يجب التوسع في ذلك ليمتد نطاق الصورية ليثمل كافة العقود الرسمية؛

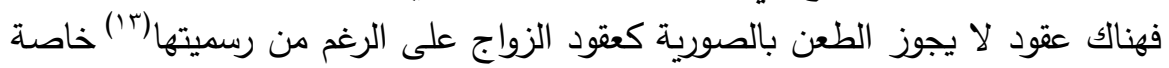

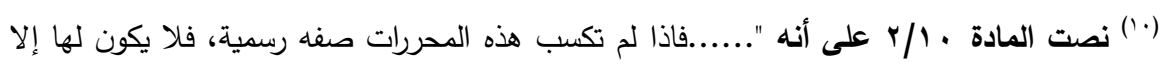

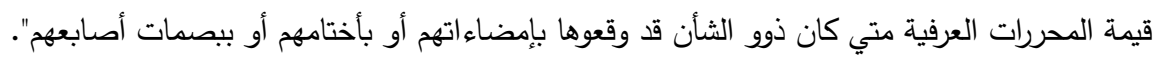

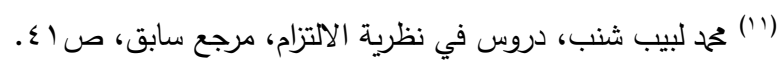

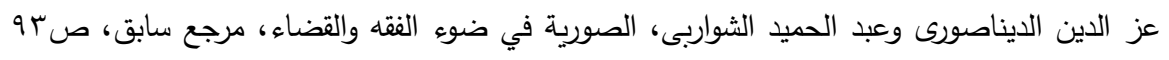
وما بعدها. أحمد مرزوق، نظرية الصورية في التشريع المصري، المرجع السابق، صان •ـ؛ وما بعدها.

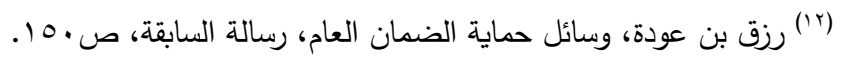

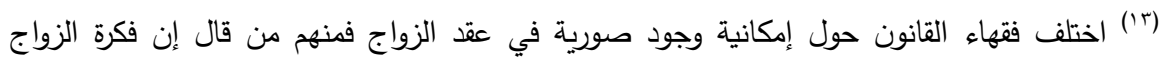

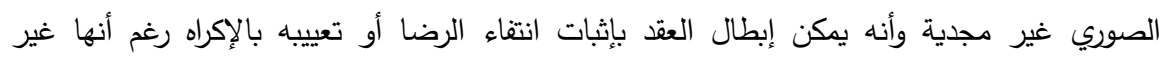

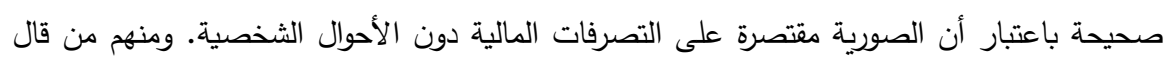

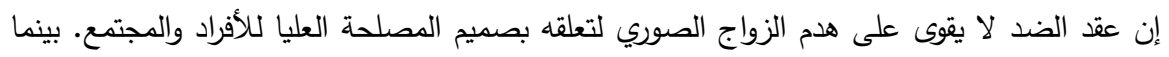

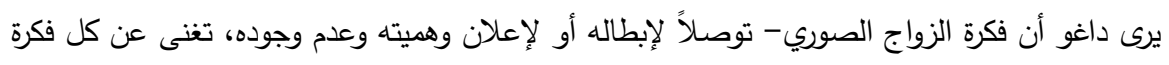

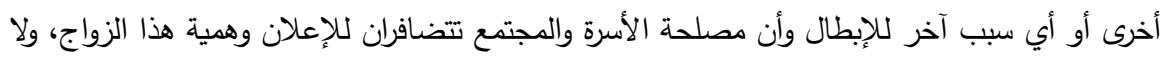

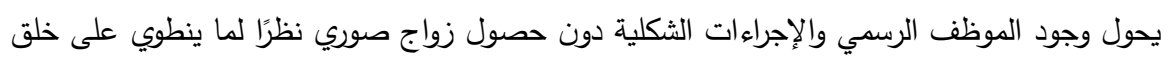

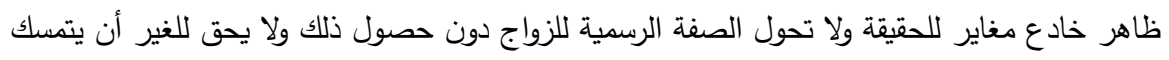

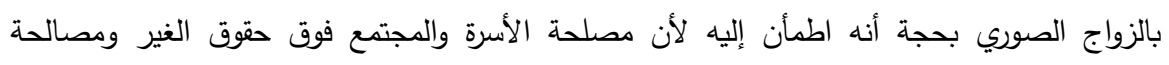

\section{$(r \vee r$.}


نطاق الصورية

الباحث/ عماد محمد حسن القتيشي

في البلاد العربية والإسلامية، فلا يمكن للصورية أن تنال من عقد الزواج وانعقاده إلا أنه

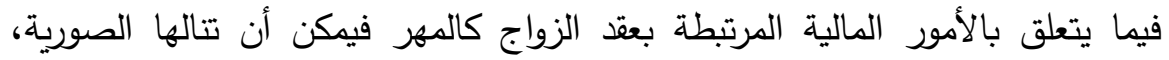

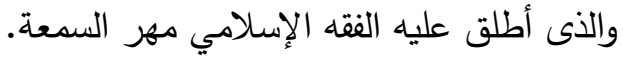
ويثور التساؤل حول أثر تسجيل أو شهر العقود الواقعة على عقار في السجلات

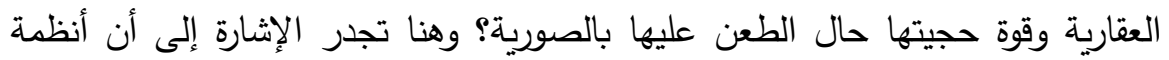

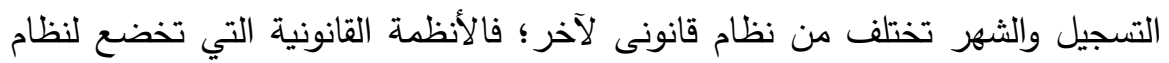

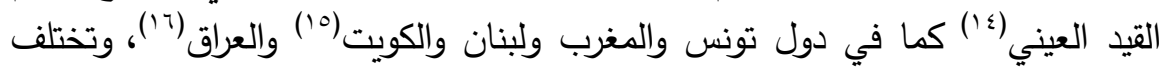

المالية. مشار إليه في عبدالله سامى، نظرية الصورية في القانون المدني، المرجع السابق، هامش $.11 \cdot-1 \cdot 90$

(\{) (1) وسمى كذلك لأن العقود المتعلقة بعقار أو بحق عيني عقاري لا تسجل بحرفتيها في السجل

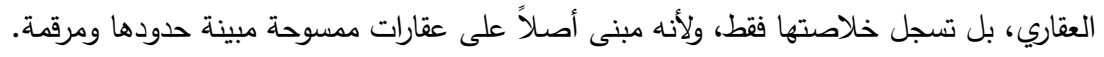

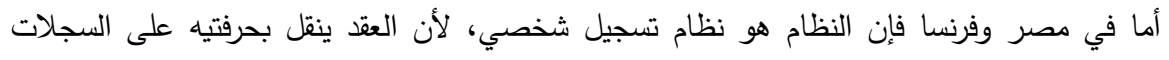

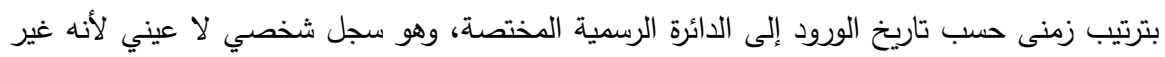
مرتكز على العقار كوحدة عقارية مرقمة، بل يرتكز على اسماء الفرقاء وتاريخ الورود.

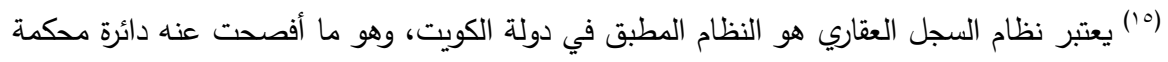

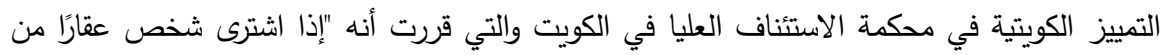
شخص آخر بعقد غير مسجل وصدر له حكم بصحة ونفاذ هذا العقد ولم يسجل الحكم أيضًا، ثم تتازع

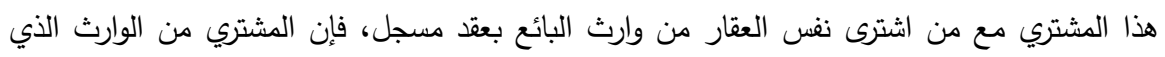

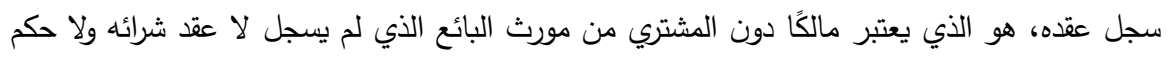

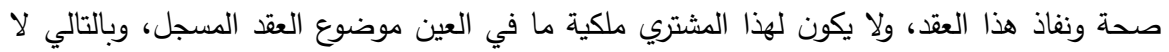

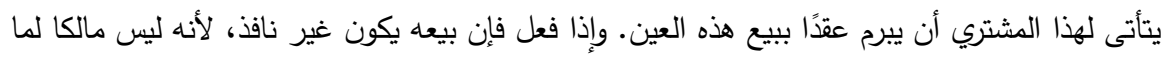

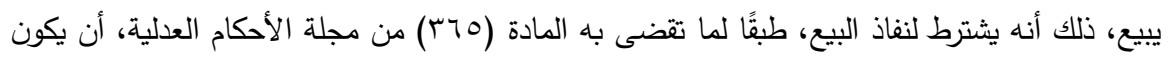

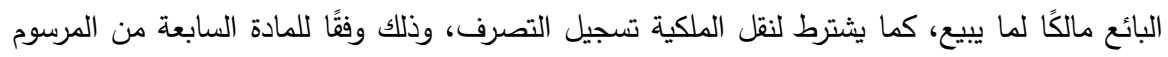

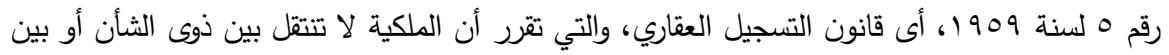

غيرهم إلا بالتسجيل".

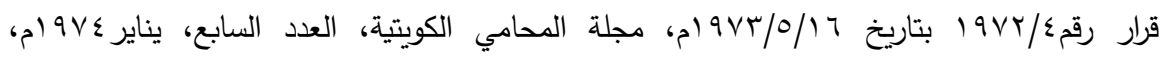

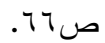

('1) نصت المادة ^^ه من القانون المدني العراقي على أنه "بيع العقار لا ينعقد إلا إذا سجل في

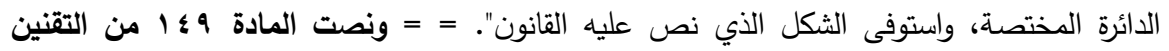

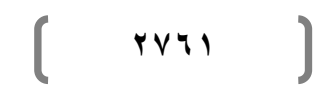


المدني العراقي بأنه "لا يجوز الطعن بالصورية على التصرفات الواقعة على عقار بعد تسجيلها في دائرة الطابو".

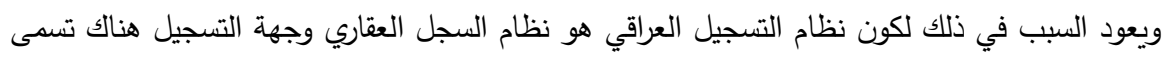

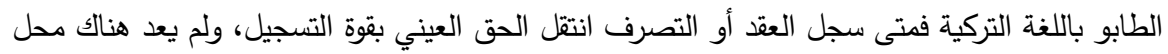

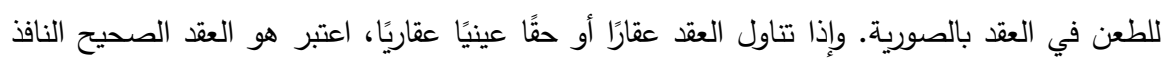

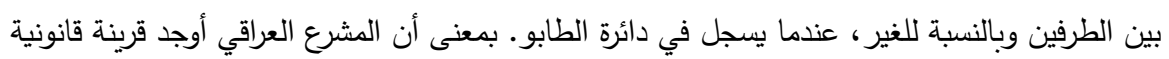

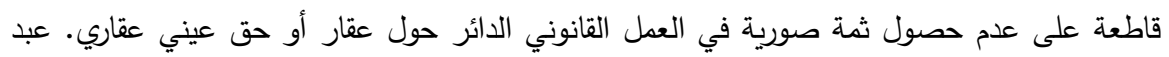

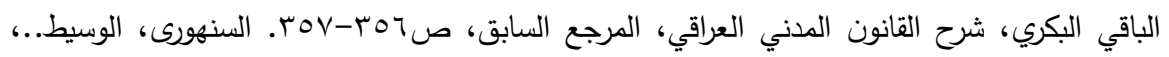

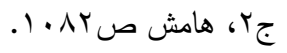

وعليه قضت محكمة التمييز العراقية بأن "عقد بيع العقارات خارج دائرة التسجيل العقاري يعد باطلاً

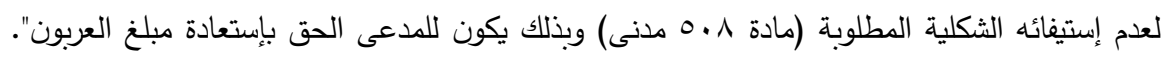

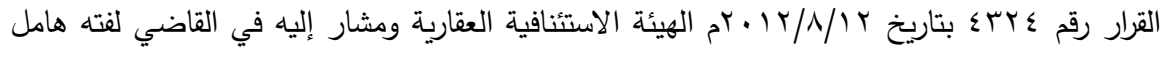

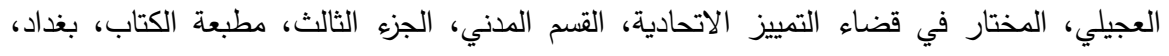

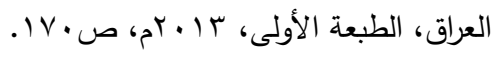

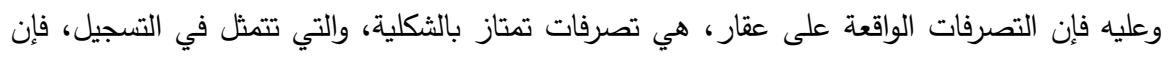

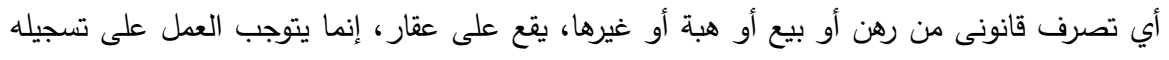

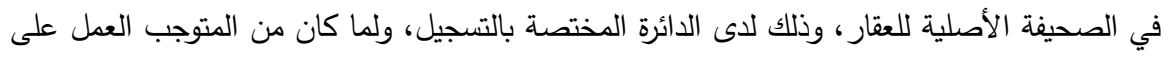

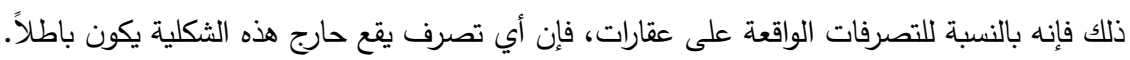

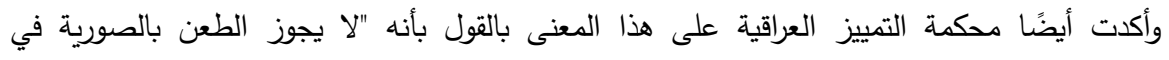

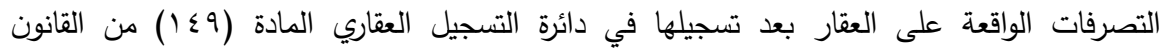

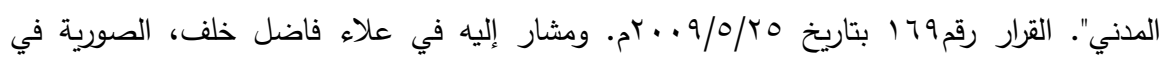

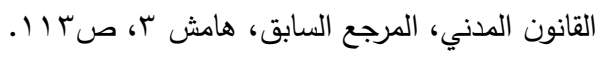

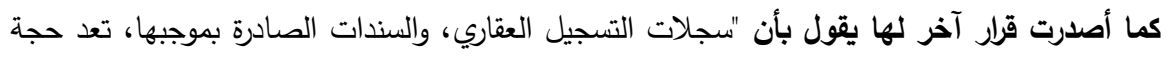

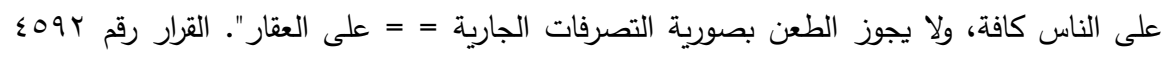

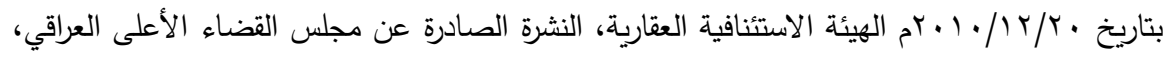

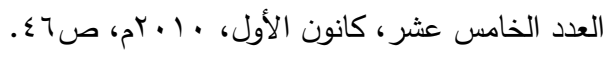

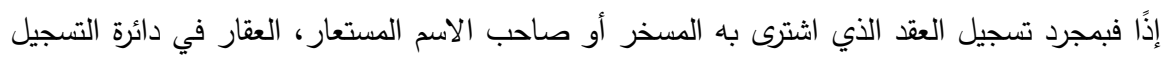

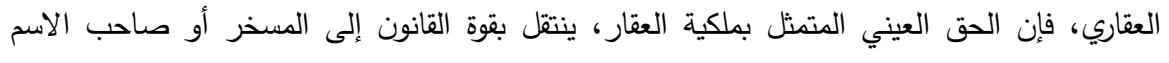

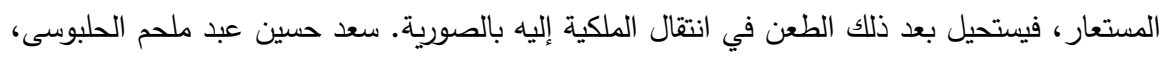

\section{$(\operatorname{rvar})$}


نطاق الصورية

الباحث/ عماد محم حسن القتيثي

عن الأنظمة القانونية التي تخضع العقارات فيها لنظام التسجيل الثخصي كما في مصر وسوريا وفرنسا من حيث الطبيعة والإجراءات والآثار المترتبة عليها.

فالتصرفات الواقعة على عقار بموجب النظام العقاري العيني يترتب عليه الآتي:

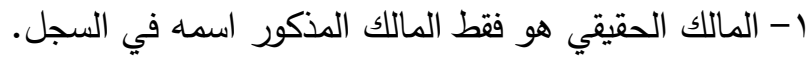

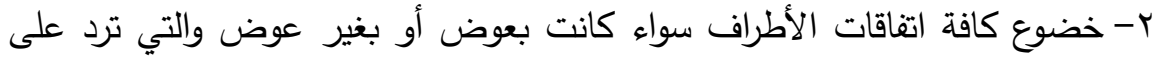
حقوق الملكية أو أية حقوق عينية أخرى، ونقلها وتغييرها وزوالها والأحكام الحائزة لقوة الأمر المقضي إلى الإعلان عنها بقيدها في دفاتر الملكية، واعتبار العقود الرضائية الاتفاقات التي ترمى إلى إنثاء حق عيني أو نقله أو تعديله أو إعلانه أو أو أوناتي

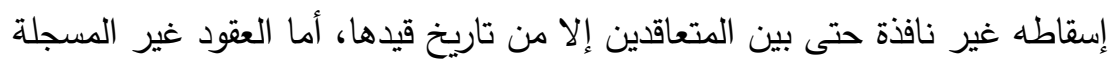

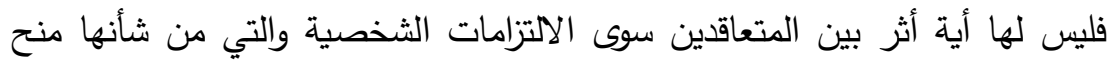

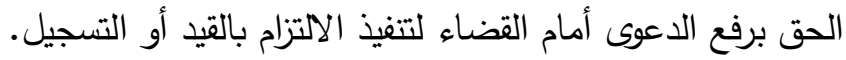
r- القيود الواردة بالسجلات العقارية لها قوة ثبوتية وحجة على الغير بثأن صحة الحقوق والوقائع الواردة فيها. وبناء على ذلك فإن مهمة التسجيل في النظام العيني هو نقل الحق العيني وتطهيره من العيوب التي قد تثوبه، وله قوة ثبوتية تجاه الكافة على السواء بمجرد إشهاره وإعلانه. من. إلا أن الأمر يختلف في الأنظمة القانونية التي تخضع العقارات فيها لنظام التسجيل

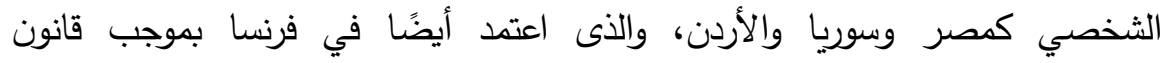

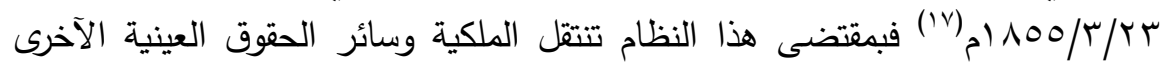
فيما بين الأطراف بنفس أثر العقود العادية وبالتاريخ ذاته الثابت فيه ميعاد تتظيم هذه

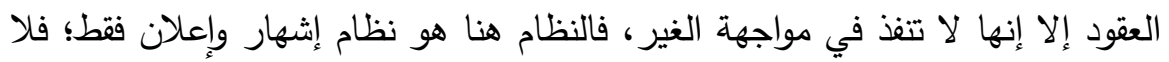

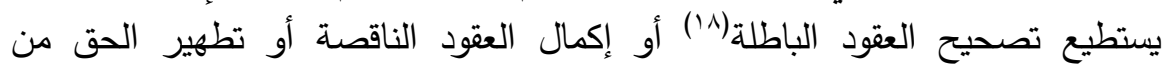

إبرام التصرف القانوني بطريق التسخير ، بحث منشور في مجلة الحقوق- جامعة النهرين، المجلد الثامن،

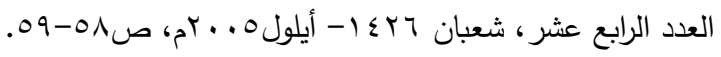

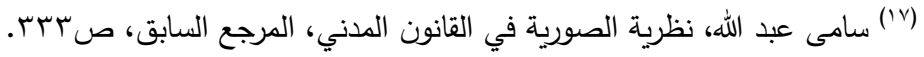

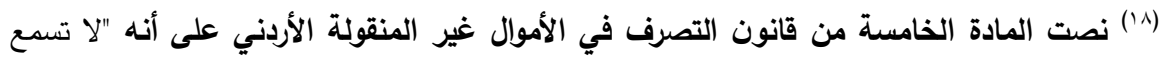

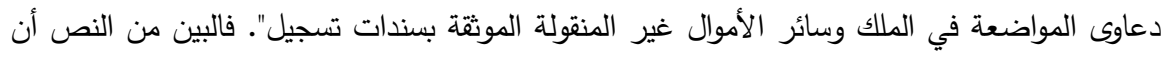
الدحاكم الأردنية ممنوعه من سماع دعاوى الصورية إذا كانت الدعاوى تتعلق بعقارات صدرت سندات

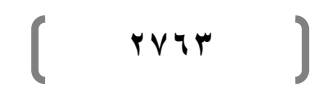


العيوب التي قد تشوبه، فالأصل أن النظام الشخصي في التسجيل يجرى وفقًا للاسماء لا بحسب العقارات، وبالتالي فليس لقيوده الحجية الكاملة وقوة الإثبات المقرة لنئل لنظام

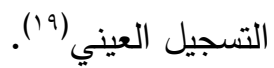
إلا إنه تجدر الإشارة هنا إلى إنه يوجد في مصر بالإضافة لنظام السجل الشخصي

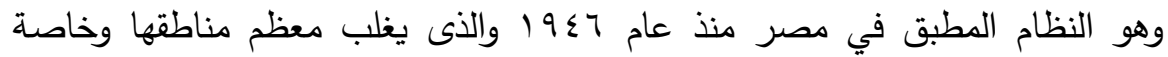

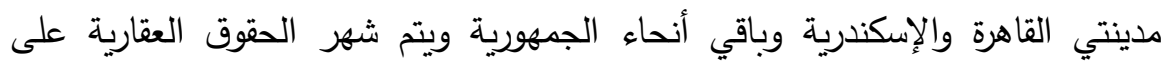

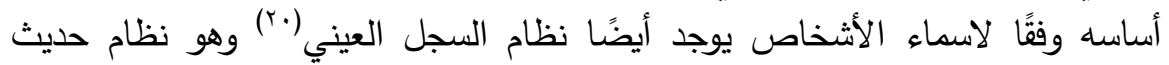

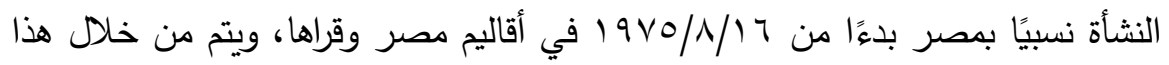

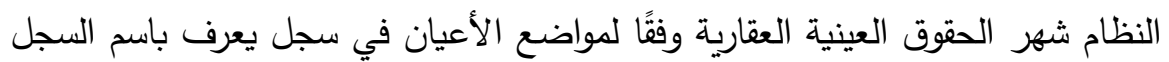
العيني أو العقاري حيث يخصص لكل عقار صفحة تعرف بالصفحة العقارية أو صحيفة السجل العيني تقيد فيها كافة التصرفات والحقوق والتغييرات التي تطرأ عليها، فالتسجيل بعان

تسجيل بها. ولهذا فليس من حق البائع أن تجيبه المحاكم إلى طلبه لثطب اسم المشتري الصوري عن صحيفة العقار ليعود باسمه ويبقى العقار على اسم المشتري.

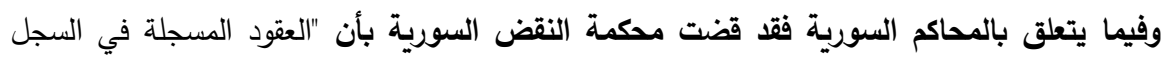

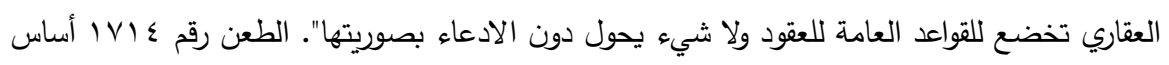

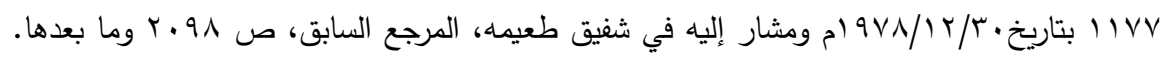

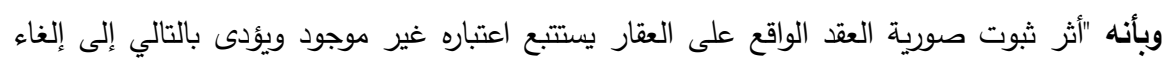

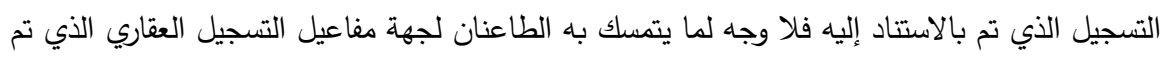

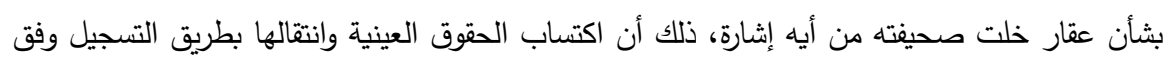

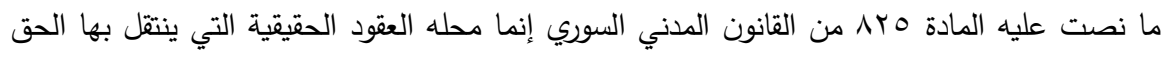

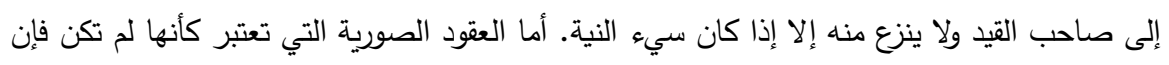

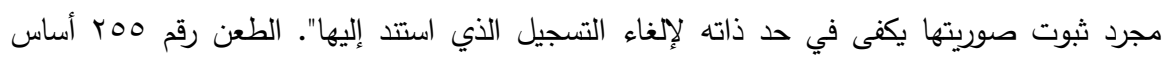

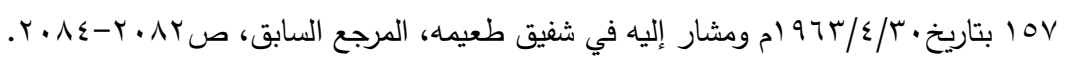

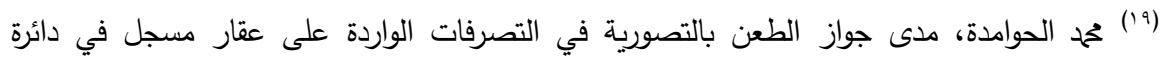

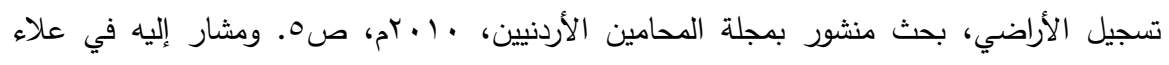

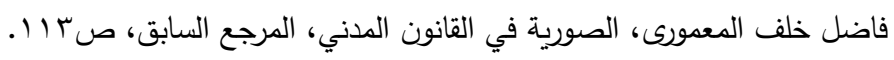

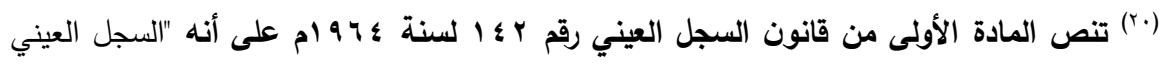

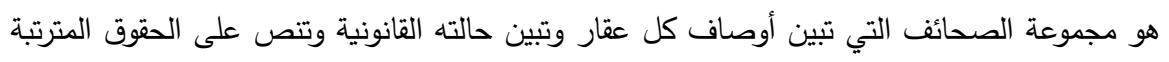
له وعليه وتبين المعاملات والتعديلات المتعلقة به".

\section{$($ rvrs $)$}


في نظام السجل الثخصي ليس له حجية مطلقة أي يجوز الطعن بالصورية في

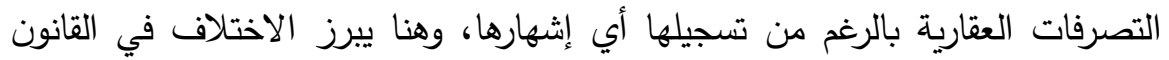
المدني المصري عنه في القوانين التي تخضع لأنظمة القيد العيني كالقانون المدني

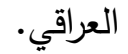

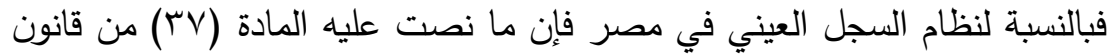

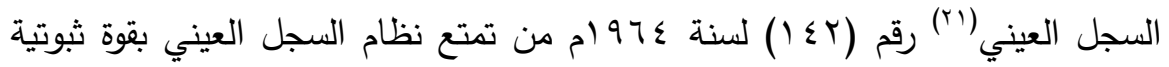

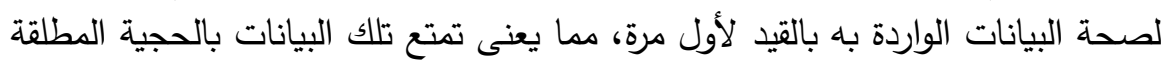

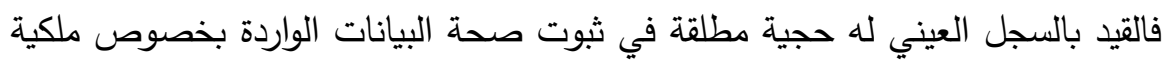

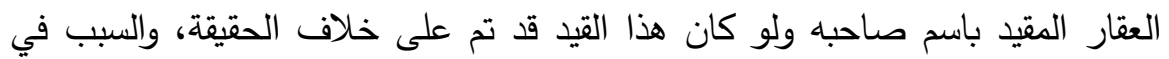

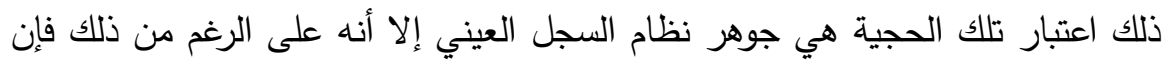

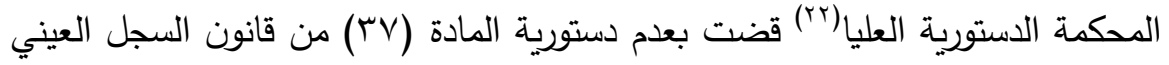

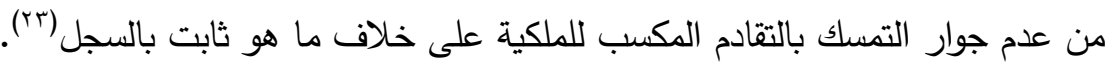

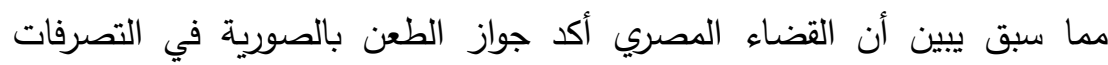

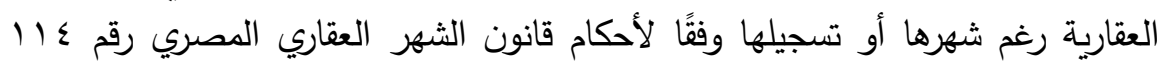

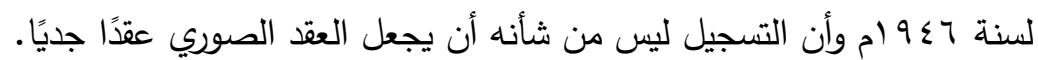

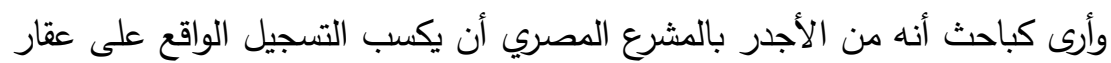

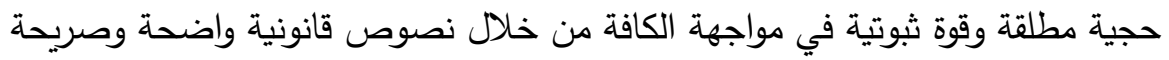

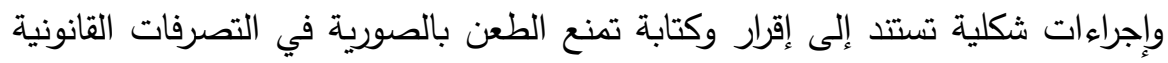
الواقعة على عقار ؛ وذلك أسوة بما فعله المشرع العراقي في المادة (9 ؛ (1) من القانون

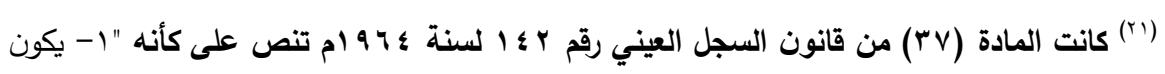

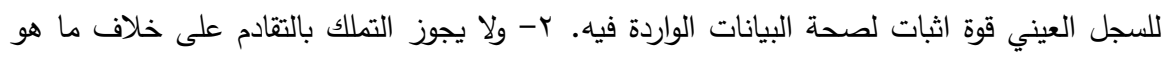

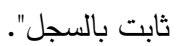

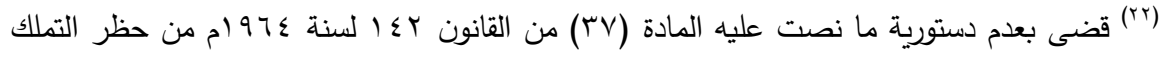

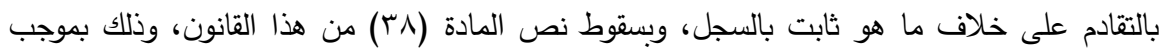

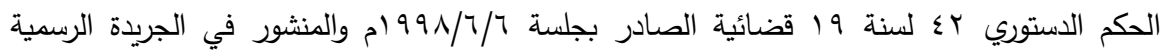

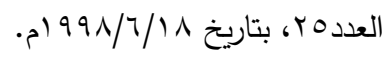
(ا) السيد عبد الوهاب عرفه، الوجيز في السجل العيني، دار المطبوعات الجامعية، الإسكندرية،

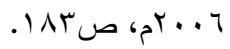


رقم • ؛ لسنة ال19 9 ام والتى نصت على أنه "لا يجوز الطعن بالصورية في التصرفات

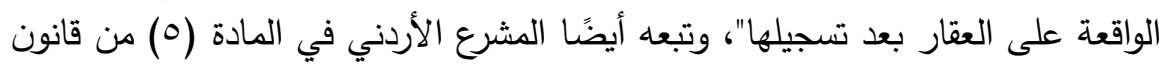

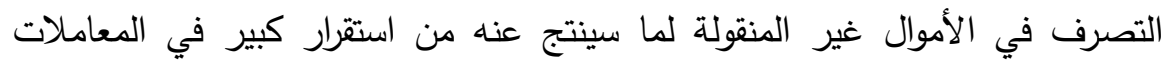

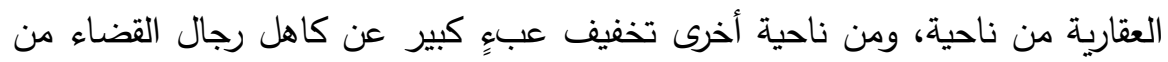

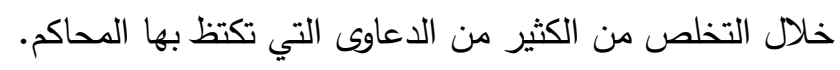

\section{الفرع الثاني \\ الصورية في العقود العرفية الصية الصئ}

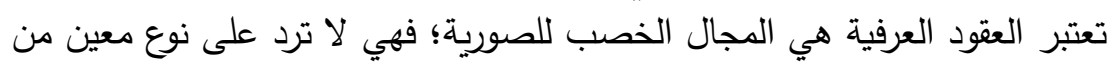

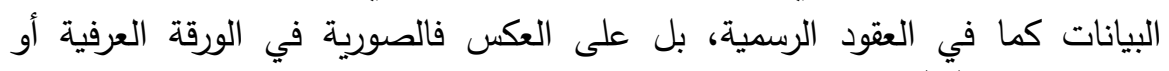

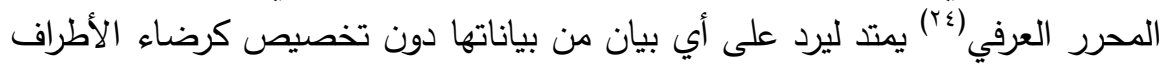

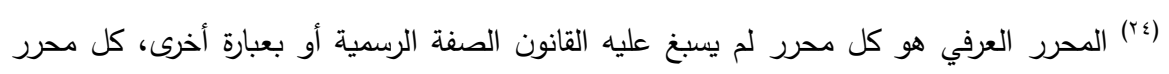

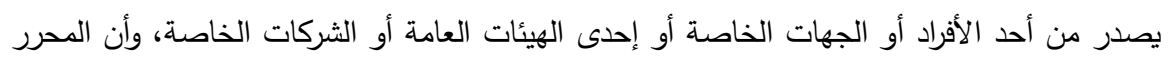

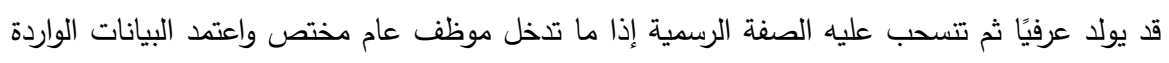

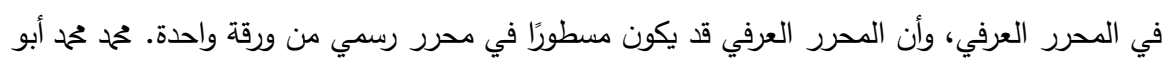

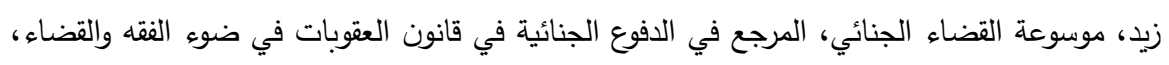

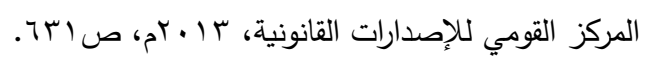
والأورلق العرفية نوعان:

النوع الأول: وهى أوراق عرفية معدة للإثبات لذلك تكون موقعة ممن هي حجة عليه فهى أدلة مهيأة.

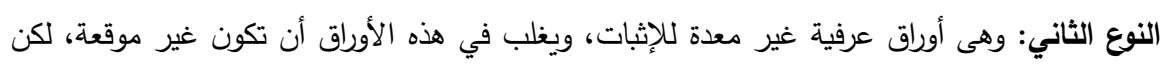

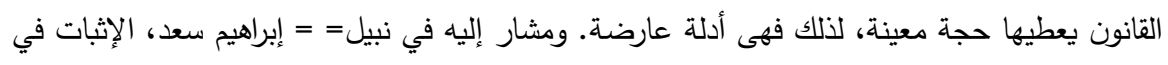

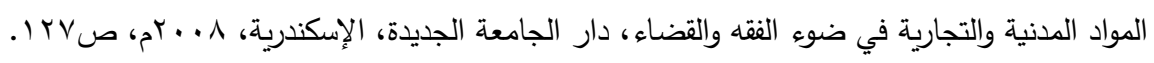

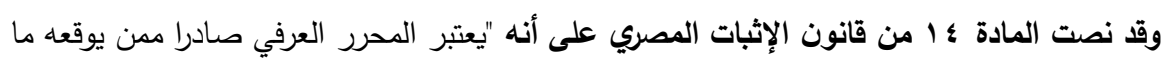

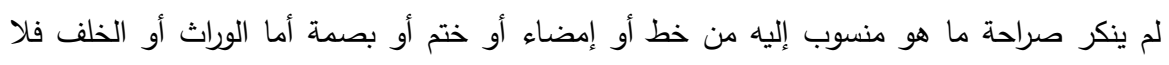

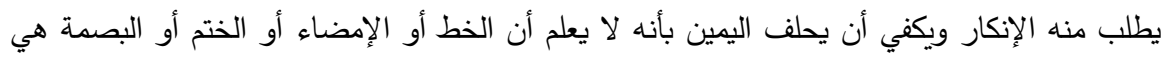

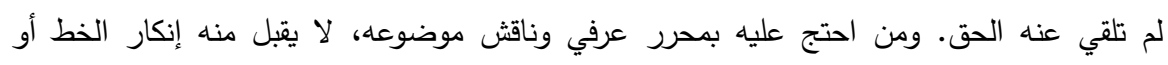
الإمضاء أو الختم أو بصمة الإصبع".

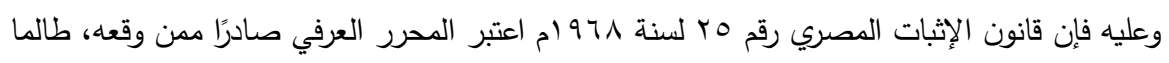

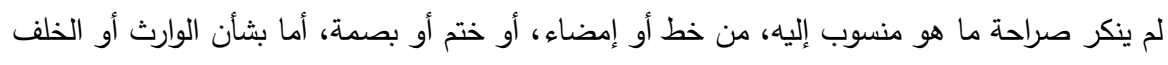

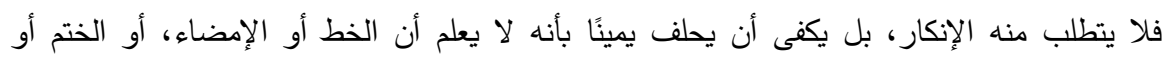

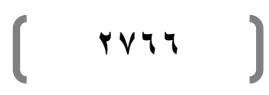


أو محل وسبب العقد، أو وجوده أو أطرافه(ror)، فعندئذ يجوز الطعن بالصورية في هذه

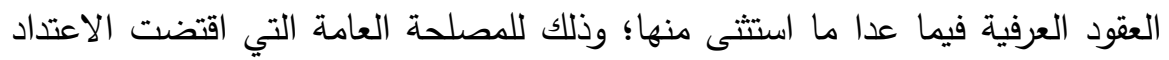

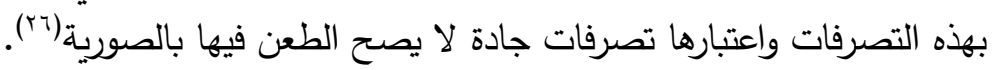
الإطلب الثاني

\section{الصورية في التصرفات الانفرادية}

آثار الطابع الاتفاقى للصورية جدلاً عنيفًا في الفقه والقضاء الفرنسي، ففي الوقت الته

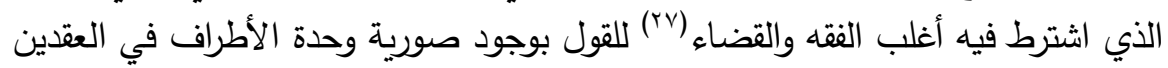
سواء الظاهر الصوري والحقيقي المستتر، بالإضافة لوحدة الموضوع والتعاصر الذهني ولئي

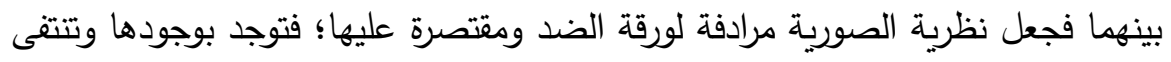

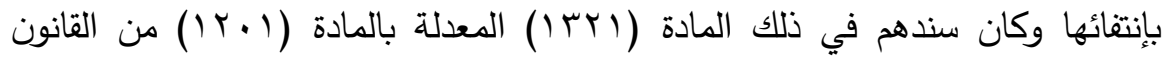

البصمة، هي لمن تلقى عنه الحق، ومن إحتج عليه بمحرر عرفي وناقش موضوعه، لا يقبل منه إنكار الخط أو الإمضاء أو الختم أو البصمة بأصابع اليد.

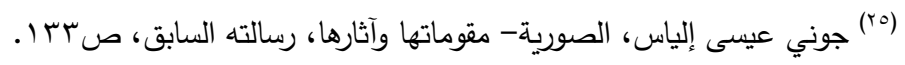

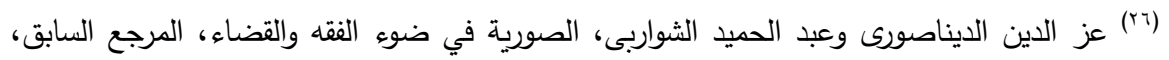

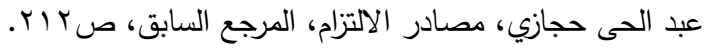

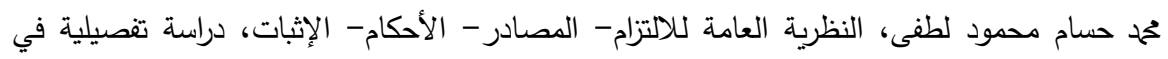

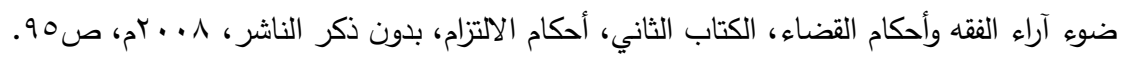

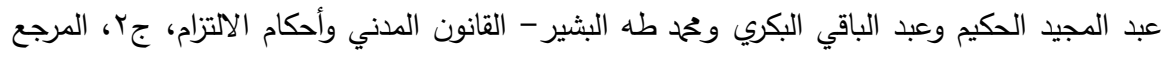

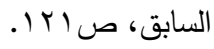
عصدت عبد المجيد بكر ، النظرية العامة للالتزام، الجزء الثاني، أحكام الالتزام، جامعة جيهان الخاصة، إلها

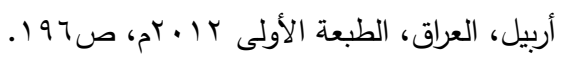

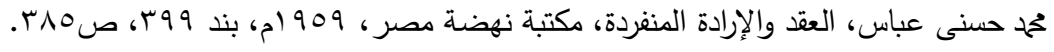

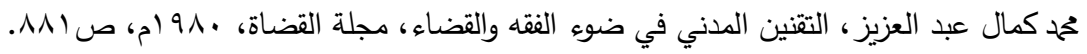
Flavian, des contre- lettres, universite de Paris, op.cit, p.104.

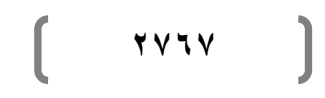


المدني الفرنسي والنصوص العربية المشابهة لها في جعل الصورية قاصرة على العقود فقط (r) وعدم تصور وجودها في التصرفات الانغرادية.

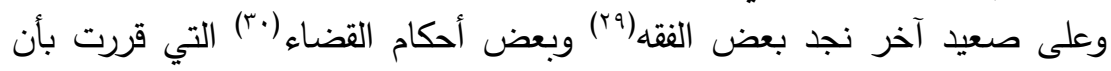
الطبيعة الاتفاقية للصورية غير متطلبة على الإطلاق ولا تستلزمها إلا في حالات

(†^) أوردت محكمة الاستئنف الأهلية "ان الصورية تكون بإخفاء حقيقة العقد في شكل عقد اخر ، أو

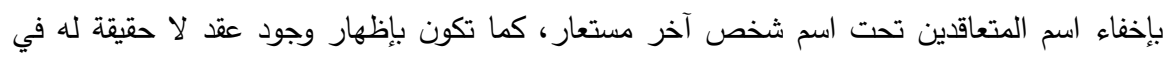

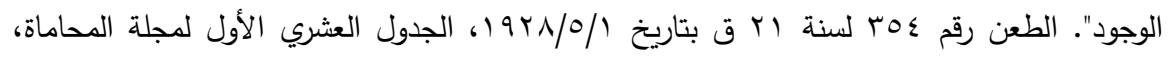

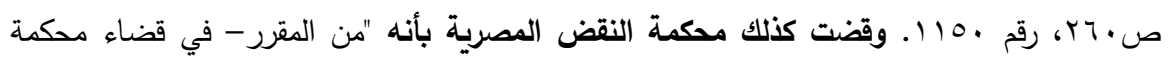

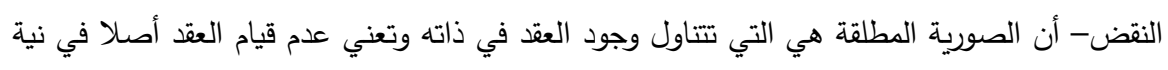
عاقديه بما يعني انعدام العقد وعدم وجوده لانعدام وجوده في الحقيقة والواقع، أما الصورية النسبية فهي في فئي

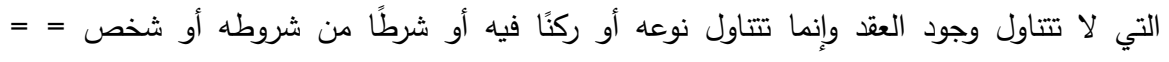

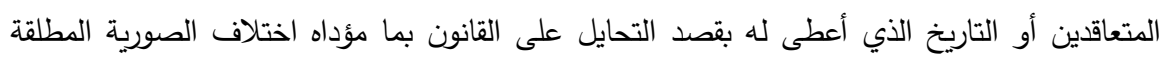

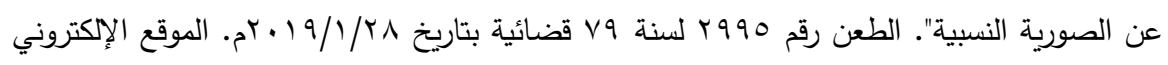
لمحكمة النقض المصرية. https://www.cc.gov.eg/judgment_single?id=111391301\&\&ja=264916

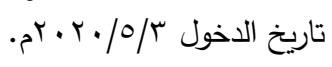

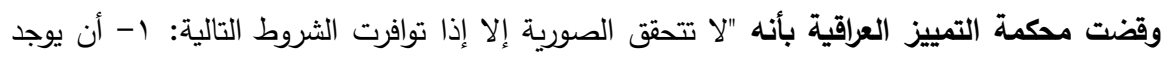

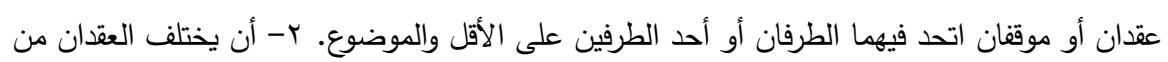

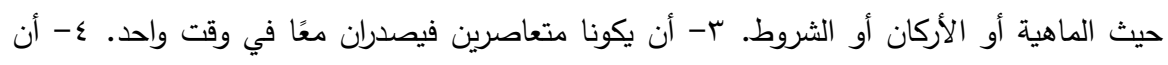

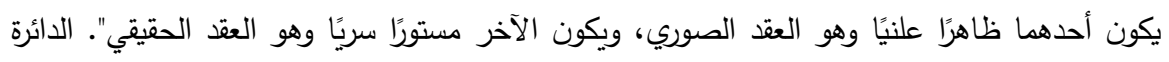

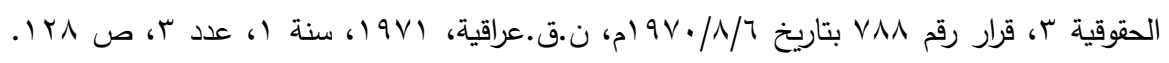

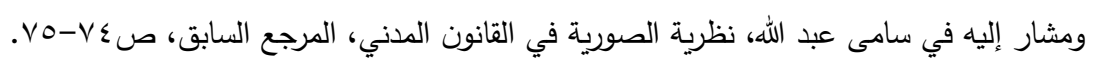

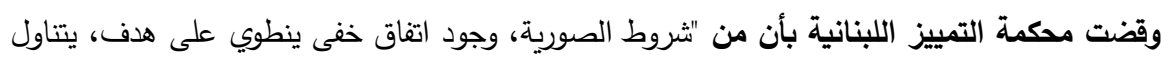

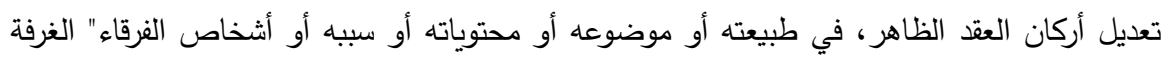

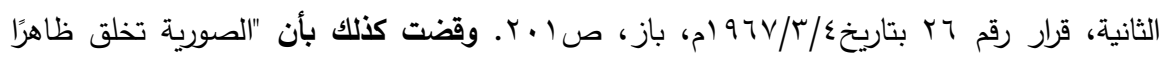

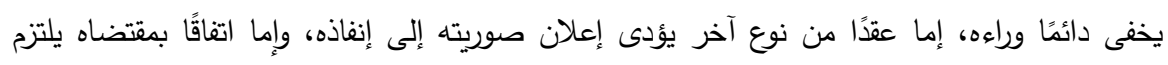

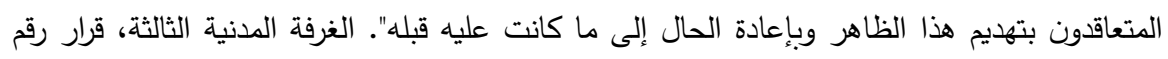

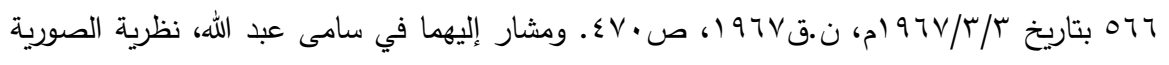

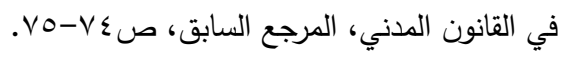

\section{$(\operatorname{rvr})$}


نطاق الصورية

الباحث/ عماد محمد حسن القتيشي

الإثبات فقط لأهميتها، وهو أمر نستتتج منه اتساع نطاق الصورية لتصبح ورقة الضد

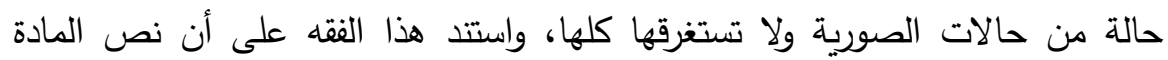

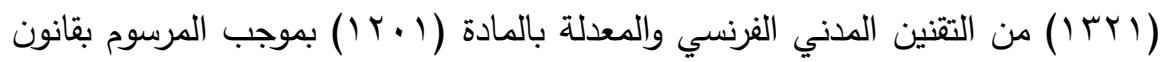

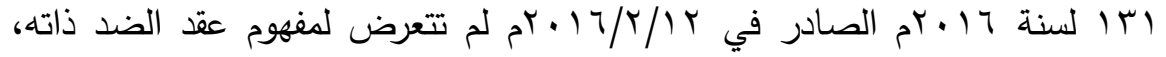

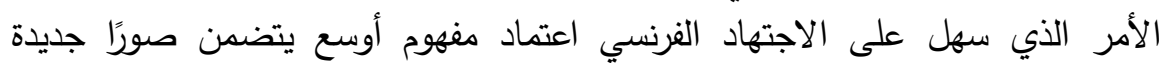

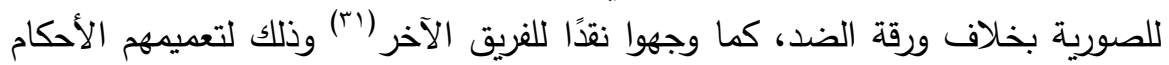

(r9) منذر الفضل، الموجز في شرح القانون الددني العراقي، الجزء الثاني في أحكام الالتزام مع المقارنة

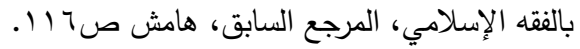

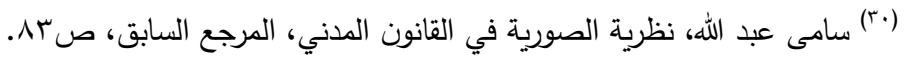

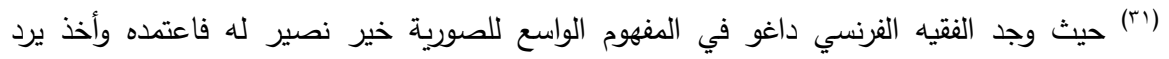

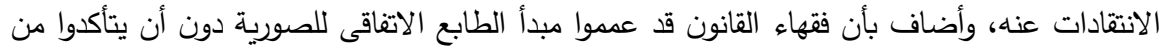

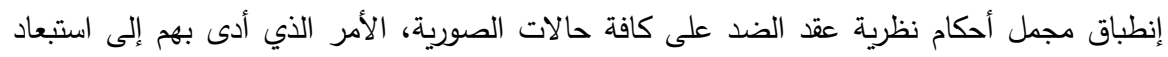

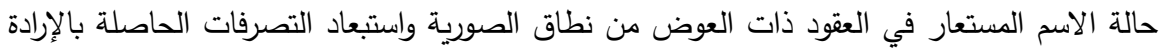

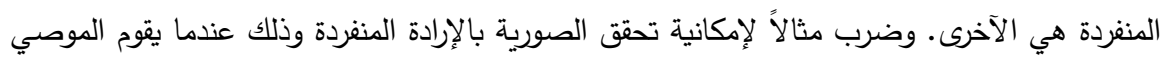

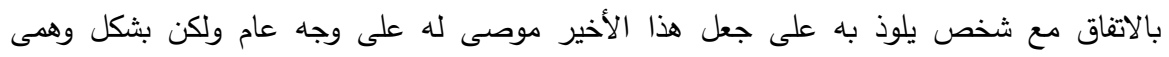

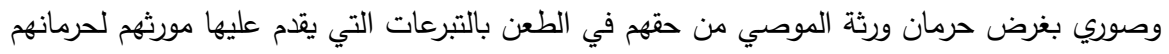

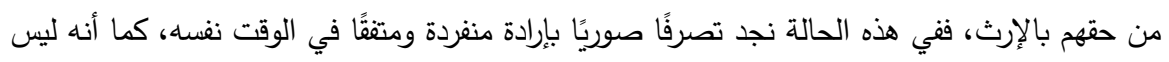

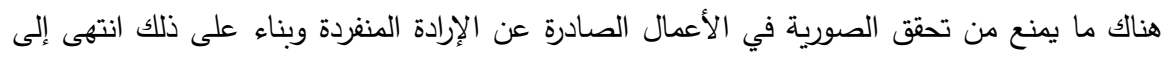

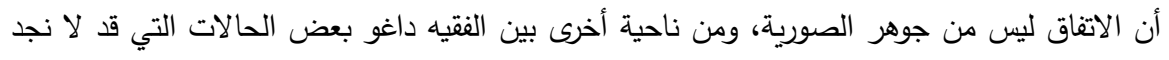

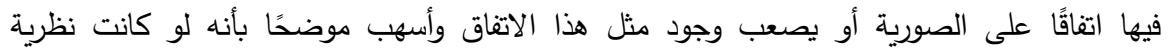

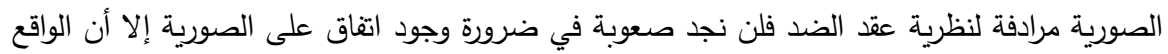

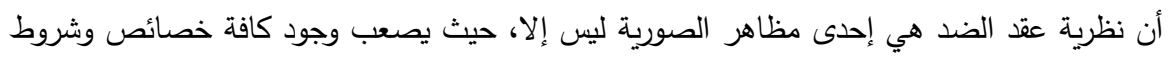

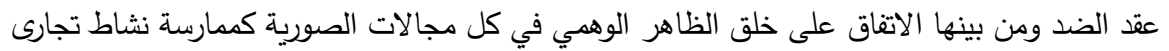

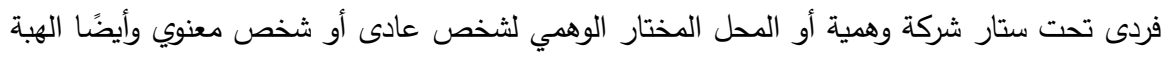

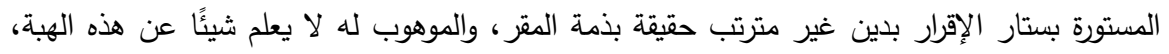

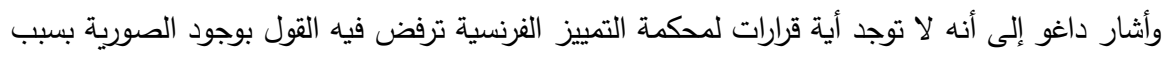

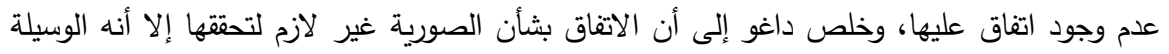

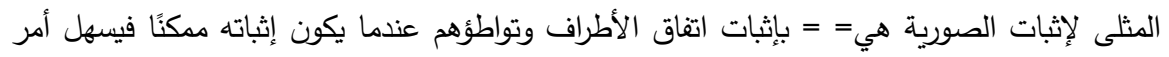

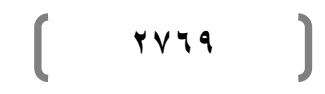


المستقاة من المادة (ITI I ) مدني فرنسي على مجمل حالات الصورية دون أن يتأكدوا

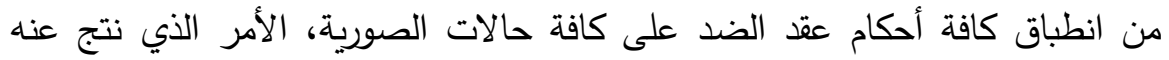

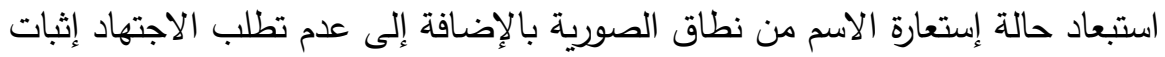

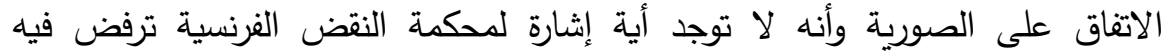

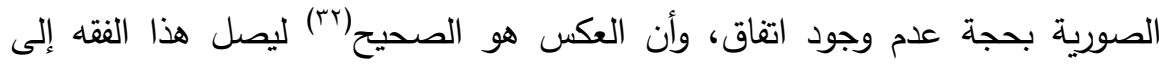

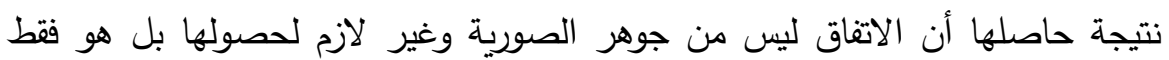
لتعزيز إثبات الصورية. وقد ترتب على هذا الانقسام الفقهي والقضائي نتائج تختلف بحسب زاوية رؤية كل

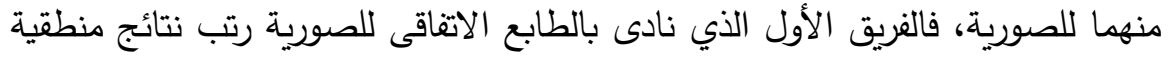

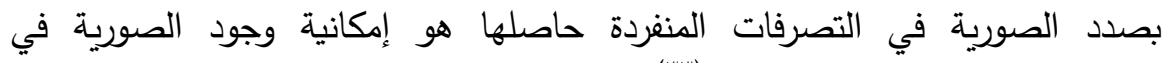

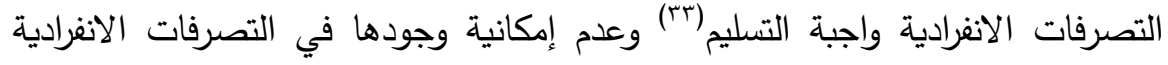

الإثبات كثيرًا كما إذا نظم الاتفاق المستتر بشكل مكتوب...إلخ. مشار إليه في سامى عبد الله، نظرية

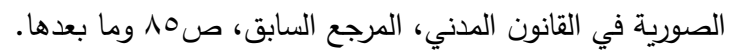

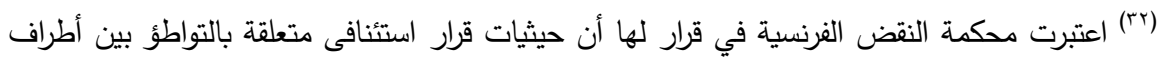

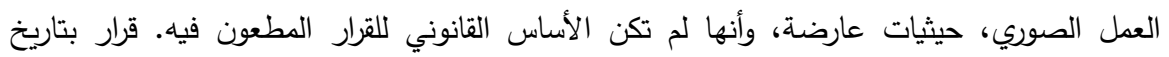

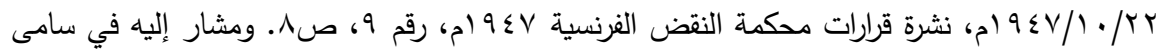

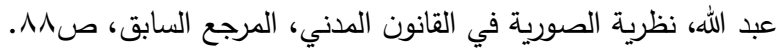

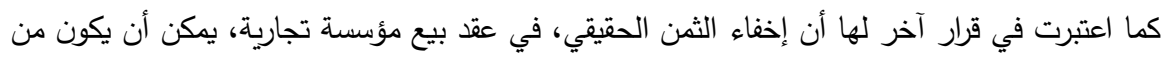

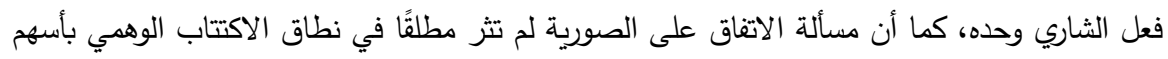

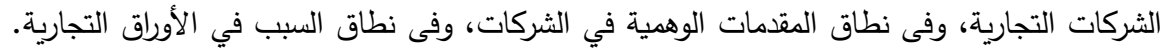

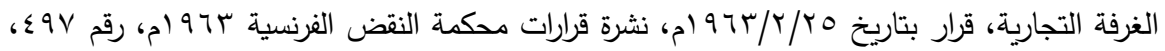

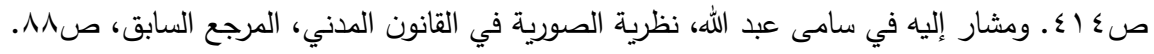

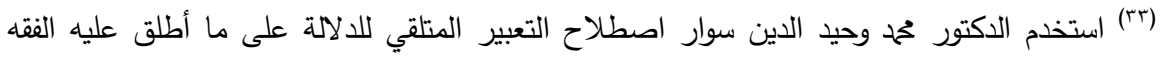
التعبير واجب التسليم والتعبير الملقى على ما أطلق عليه الفقه التعبير غير واجب التسليم بمسوغات

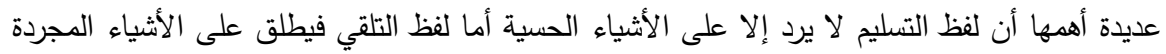

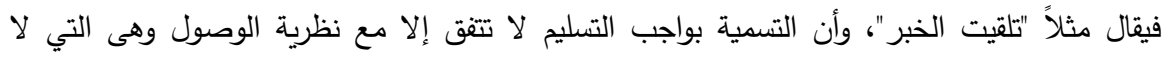
تتطلب العلم الحقيقي بالتعبير لا مجرد وصوله وتسلمه والتسمية المنتقدة تجافى مؤدى النظريتين

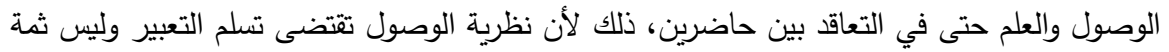

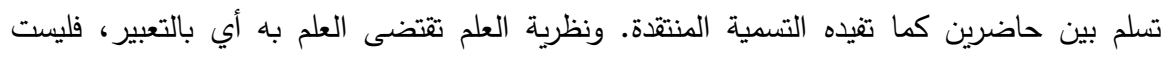

\section{$(r \vee v \cdot)$}


نطاق الصورية

الباحث/ عماد محمد حسن القتيشي

غير واجبة التسليم وهى التصرفات الصادرة من جانب واحد وغير موجهة إلى شخص

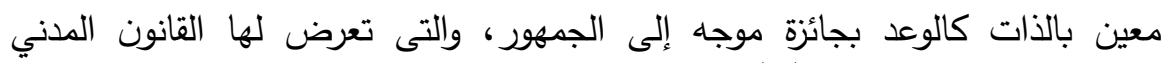

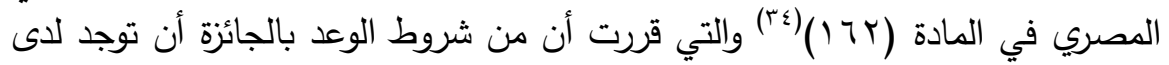

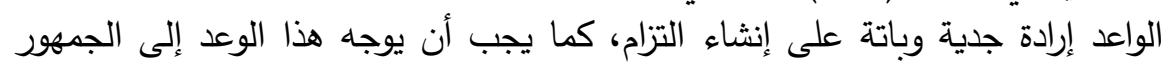

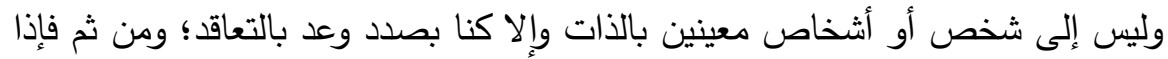

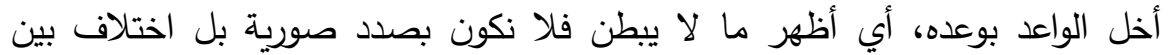

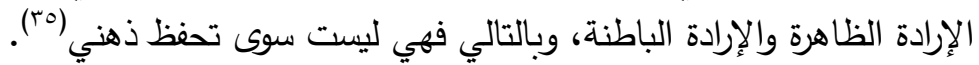

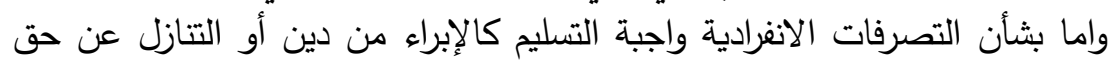

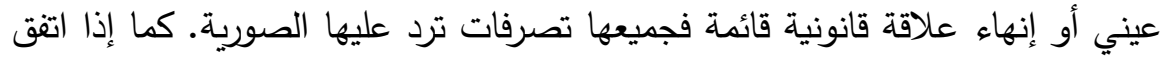

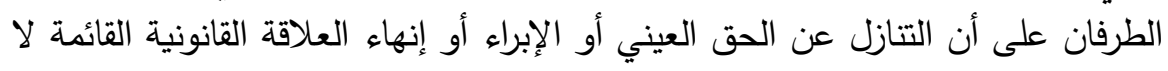

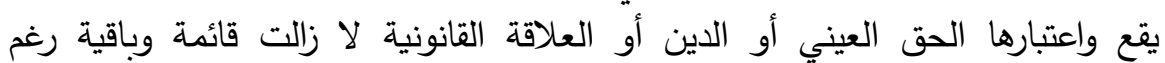
التصرف الصوري( آ؟r). وأما الفريق الآخر الذي لا يعتبر الاتفاق من جوهر الصورية واعترف بوجودها في

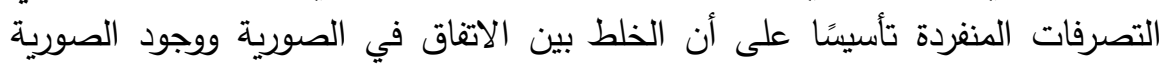

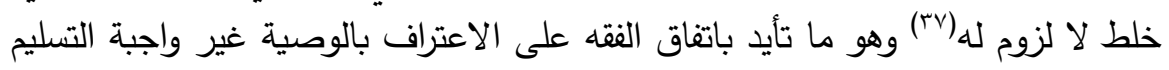

التسمية المنتقدة تفيد وجوب هذا العلم، أما التسمية المختارة فهى البت بنظريتي الوصول والعلم وسواء

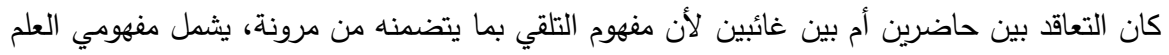

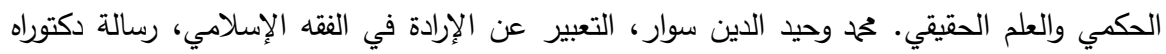

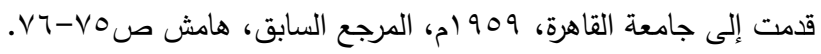

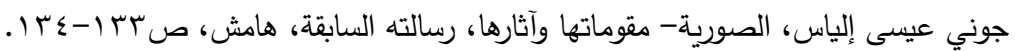

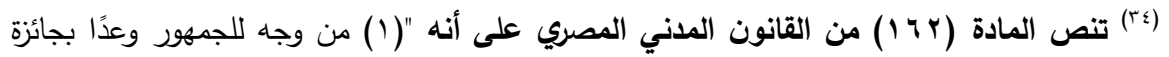

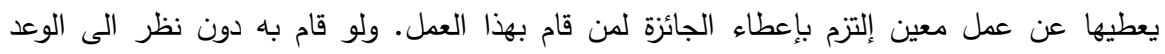

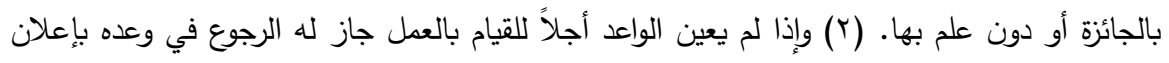

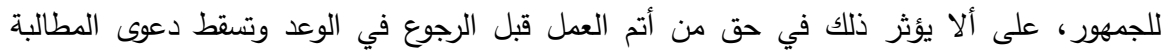
بالجائزة إذا لم ترفع خلال ستة أشهر من تاريخ إعلانه العدول للجمهور".

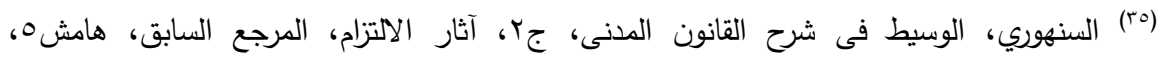
$.91 \leq 0$

(37) Josserand, op.cit., p. 240,

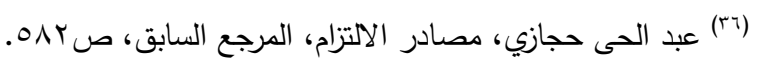

مجدى حسن خليل، رسالته السابقة، ص00.

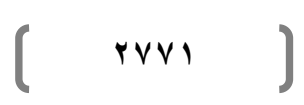




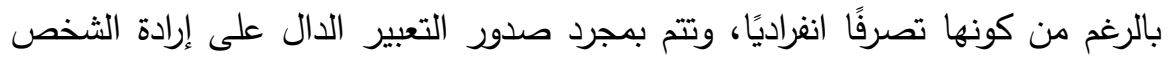

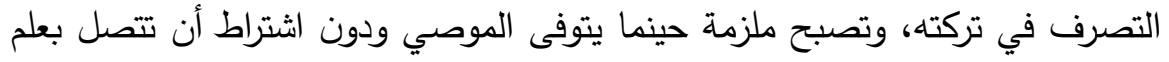

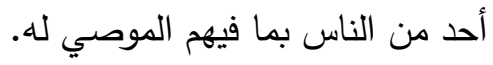
وأرى كباحث أن المثال الأخير لا يوجد به له صورية، وأن علم الأطراف واتفاقهم على النى

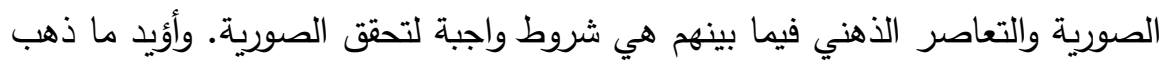
إليه الفريق الأول من الفقه بثأن إمكانية تصور حدوث الصنية الصورية على التصرية التصرفات

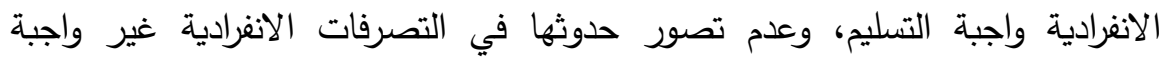
التسليم؛ فهو أمر يتتافى مع الصورية ذاتها ومن الصعب تصنية تصور حدوث صورية فية فيه. الإطاب الثالث

\section{الصورية في الدعاوى والإجراءات والأحكام القضائية الصنية}

كما تتحقق الصورية في العقود والتصرفات الحاصلة بالإرادة المنفردة، فقد أجمع

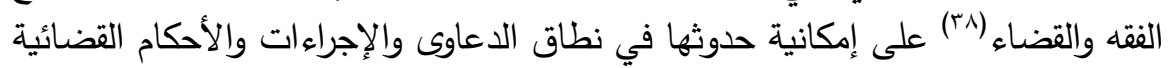

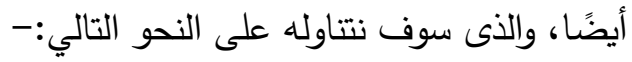

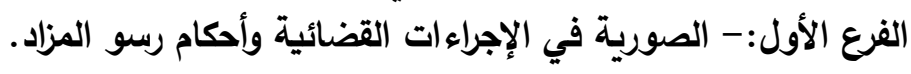
الفرع الثاني:- الصورية في الاعاوى والأحكام القضائية.

(†) قضت محكمة النقض المصرية بأن "الصورية كما ترد على العقود ترد على الأحكام وبخاصة

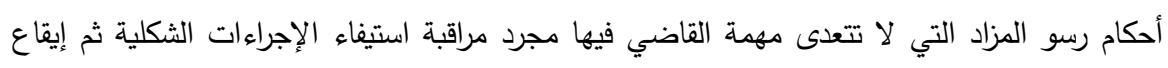

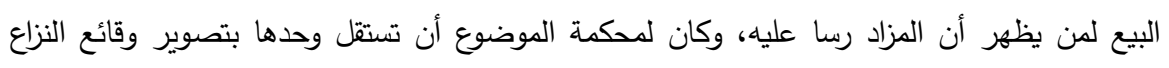

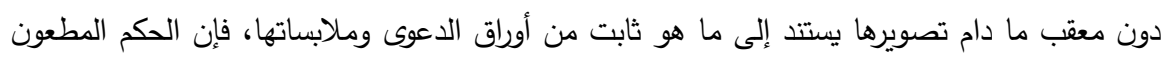

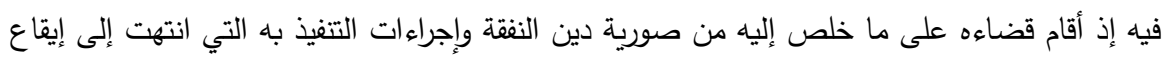

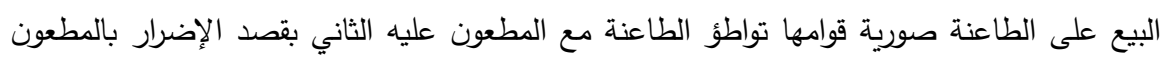

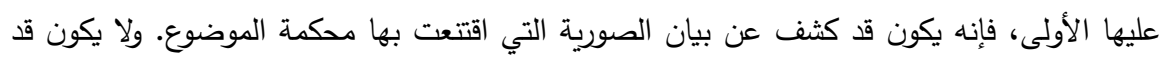

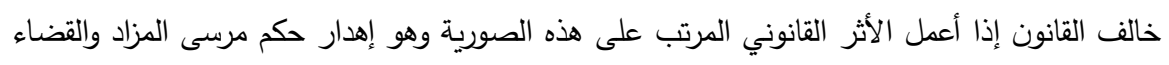

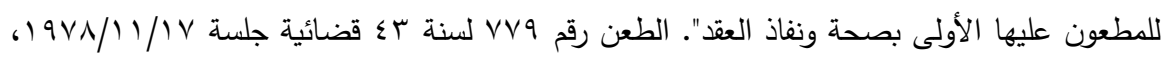

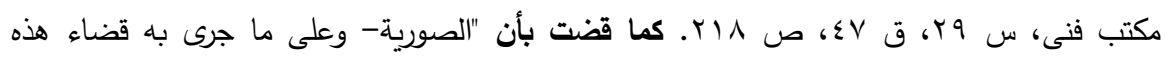

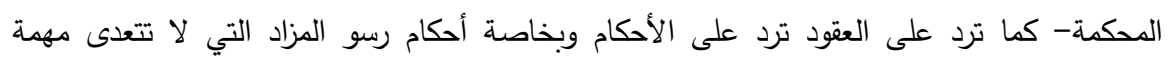

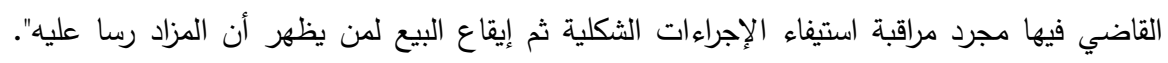

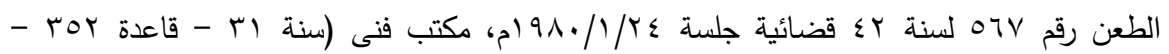




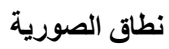

الباحث/ عماد محمد حسن القتيشي

\section{الفرع الأول}

\section{الصورية في الإجراءات القضائية وأحكام رسو المزاد}

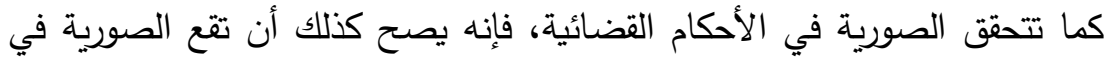

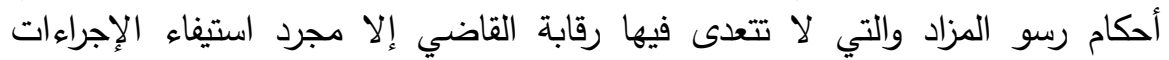

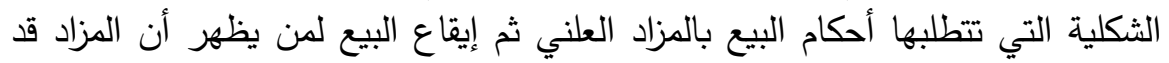

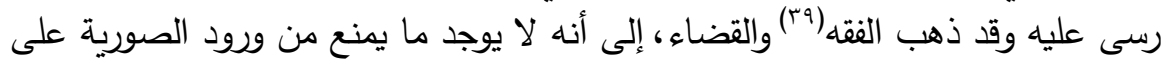

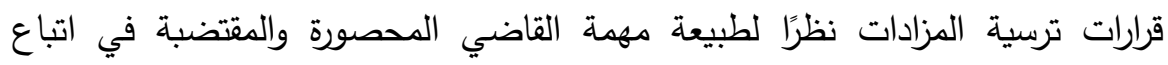

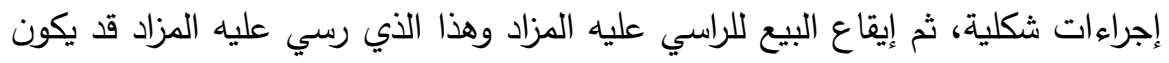

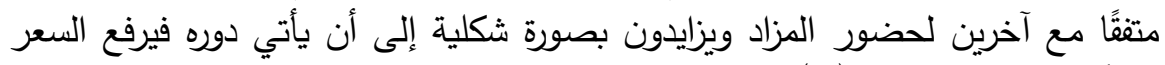

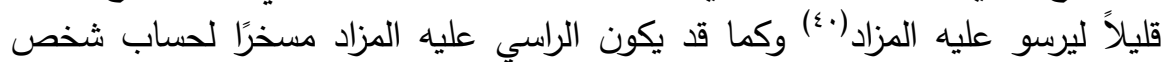

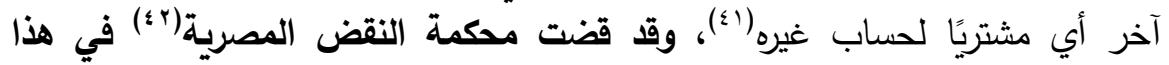

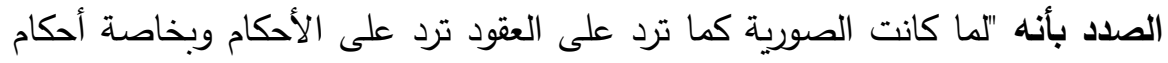
رسو المزاد التي لا تتعدى مهمة القاضي فيها مجرد مراقبة استيفاء الإجراءات التهات الثكلية، ثم إيقاع البيع لمن يظهر أن المزاد قد رساد عليه".

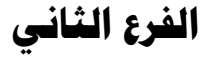 \\ الصورية في الدعاوى والأحكام القضائية}

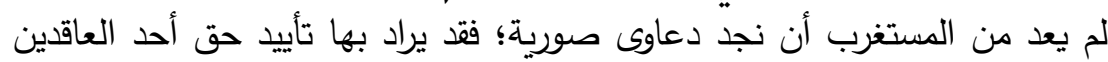
على الآخر ، وقد يراد بها تأييد حقهما أو حق أحدهما على الغير كما في العقود، ومثال

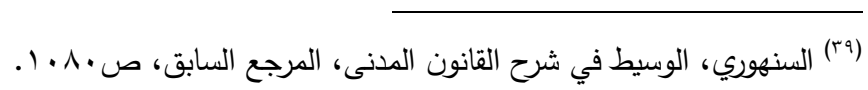

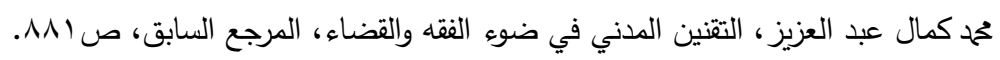

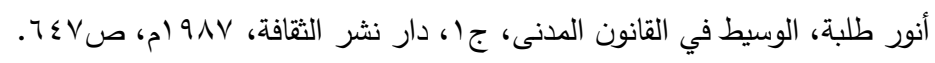

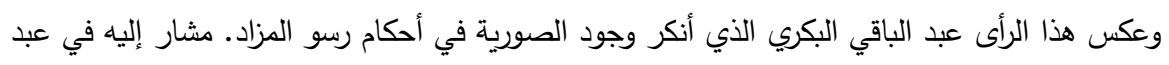

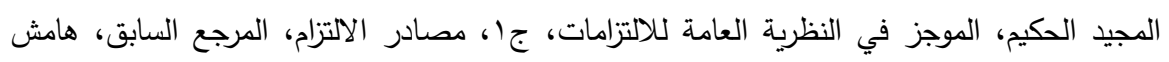

$$
\begin{aligned}
& \text { 90، ص. }
\end{aligned}
$$

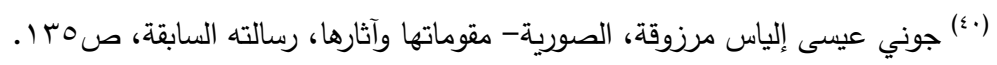

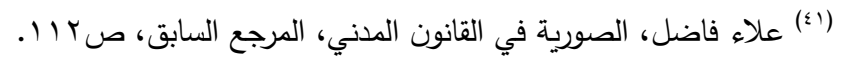

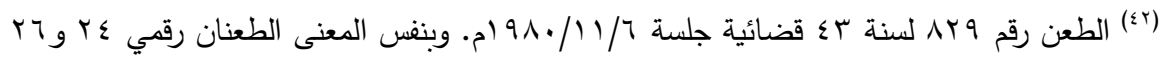

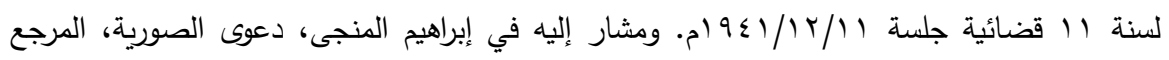

$$
\begin{aligned}
& \text { السابق، ص107. }
\end{aligned}
$$


ذلك كما لو اتفق المقرض مع المقترض على أن يقرضه مبلغ من المال بفوائد فاحشة

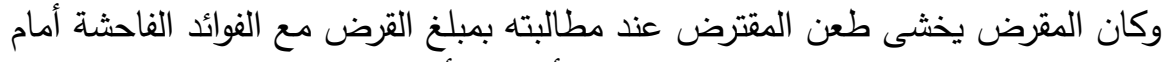

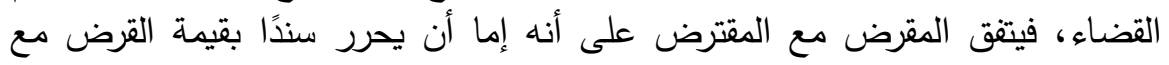

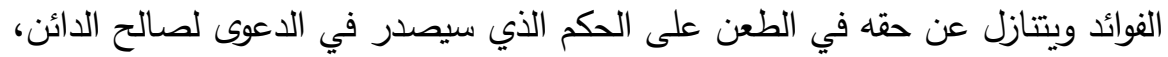

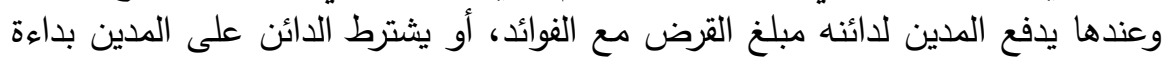

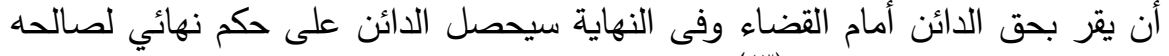

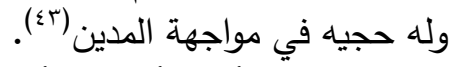

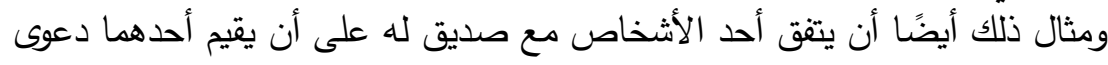
في مواجهة الآخر ليحصل على حكم قضائي بالمنع من التصرف في في ملكية عقانية التعاره،

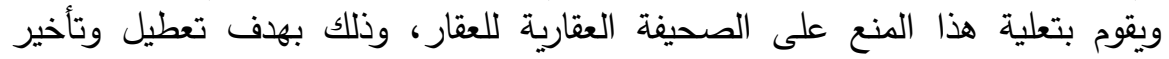
معاملات طرح هذا العقار بالمزاد العلني من قبل دائنين حقيقيين فيضر بالدين بائنين

(זّ) عز الدين الديناصورى وعبد الحميد الثواربى، الصورية في ضوء الفقه والقضاء، المرجع السابق،

أجازت محكمة التمييز اللبنانية إعلان دعوى الصورية على الأحكام القضائية، فقضت محكمة التمييز

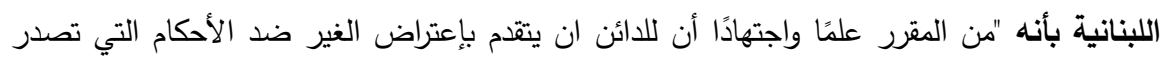

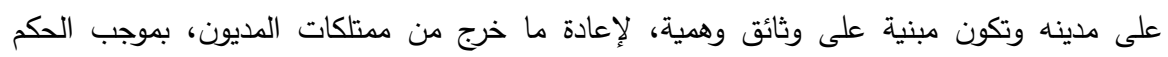

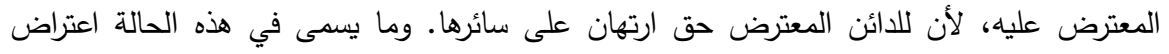

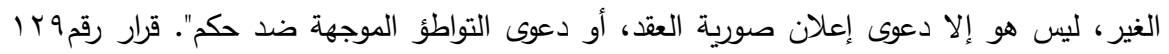

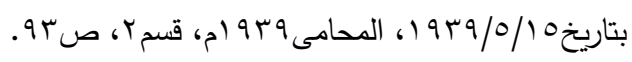

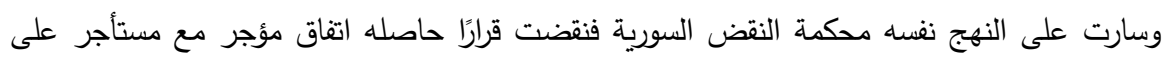

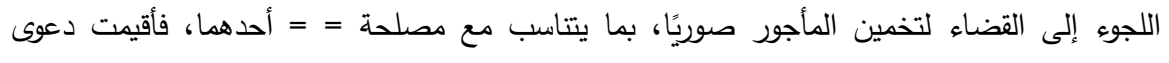

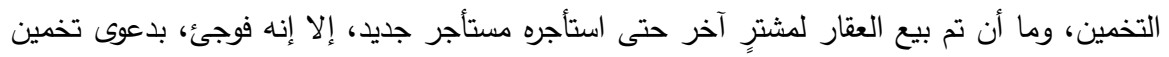

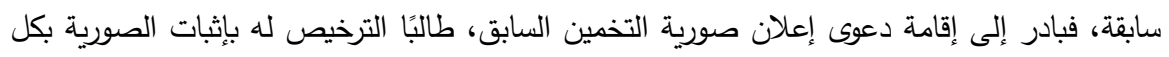

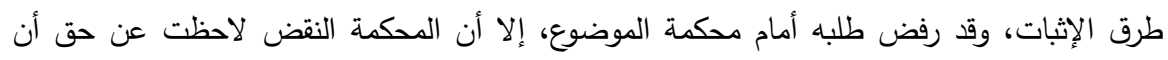

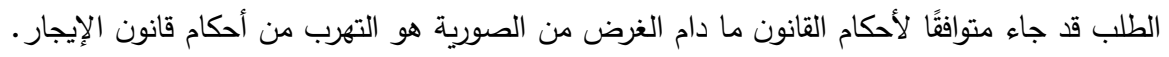
والمقصود بالتخمين هو تحديد قانوني للأجرة يتم بواسطة المحكمة حسب نسب المان قانونية محددة استنادًا

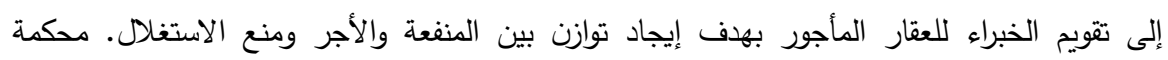

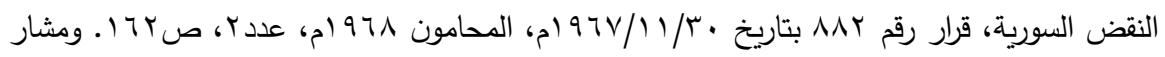
إلى الحكمين السابقين في سامى عبد الله، نظرية الصورية في التقتين الددني، المرجع السابق، 


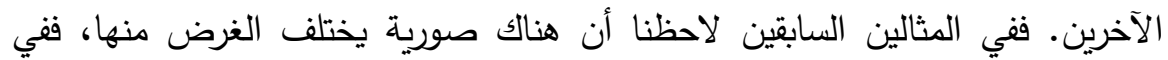

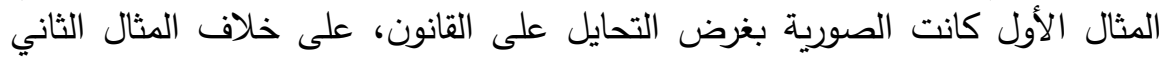

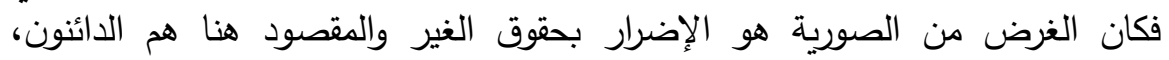

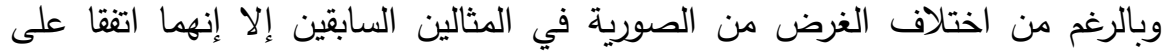

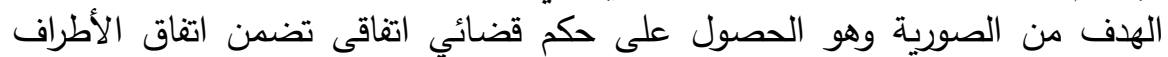

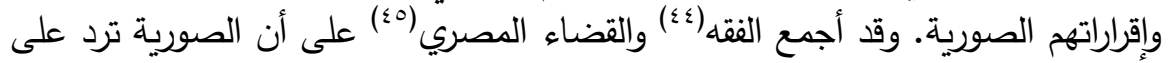

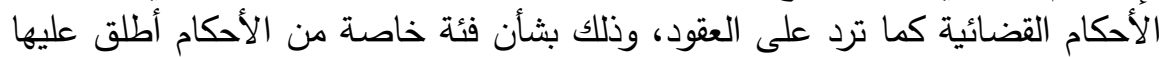

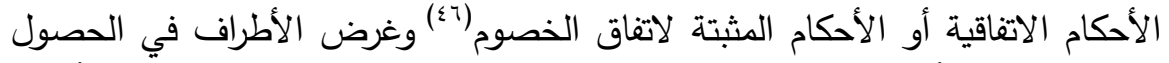

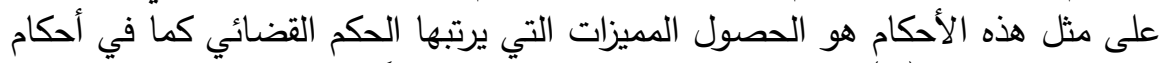

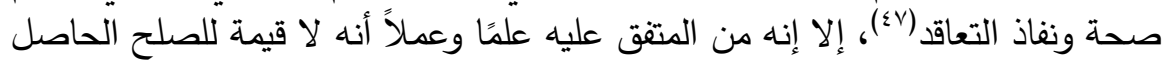

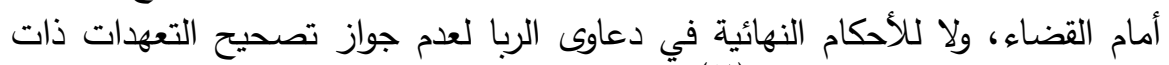

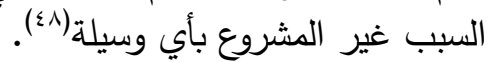

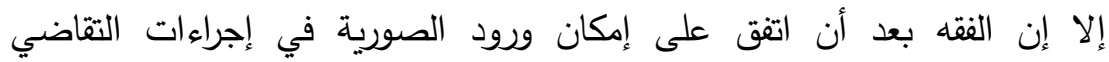

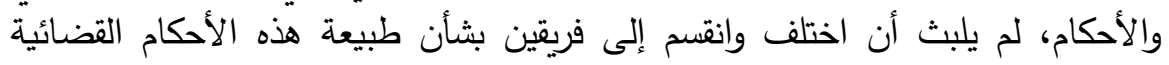
الاتفاقية، ومدى جوازيـه اعتبارها أحكامًا حقيقية أم تعد بمثابة العقود؟.

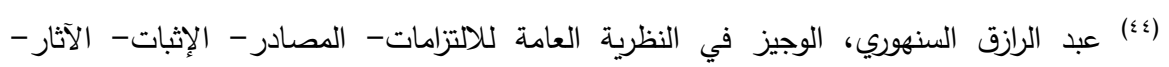

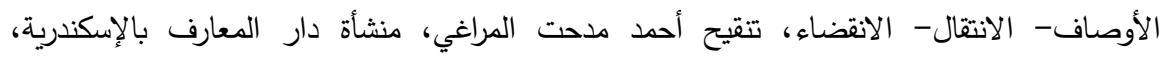

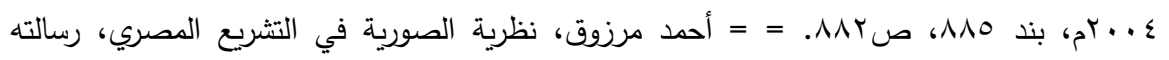

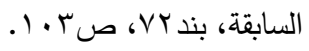

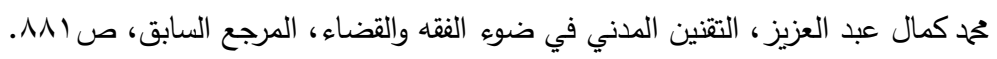

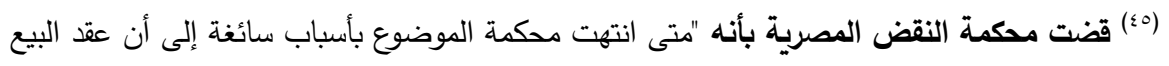

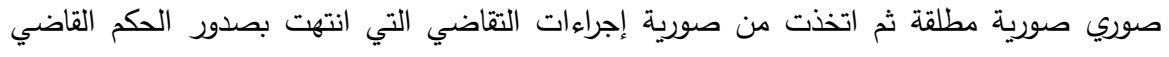
بصحة ونفاذ هذا العقد قرينة أخرى أضافتها إلى القرائن التي دللت بها على على صورية العقد فإنها لا تكون

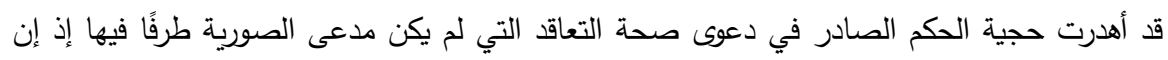

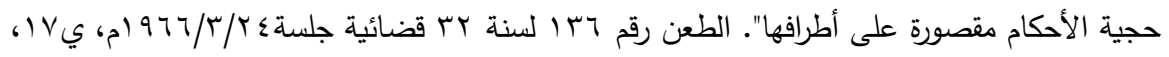

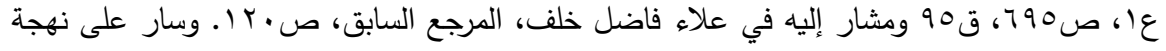
الاجتهاد السوري والللبناني.

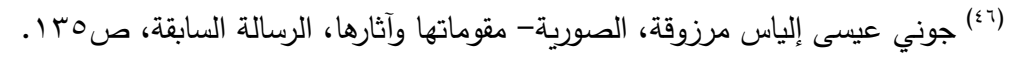

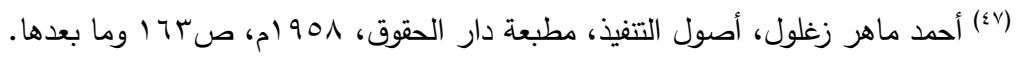

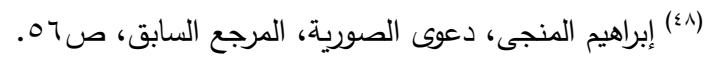




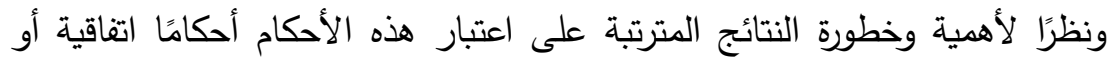

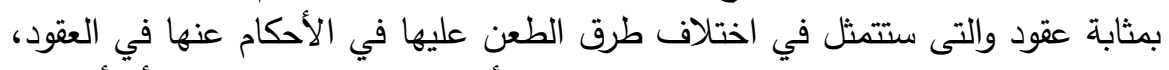
فقد استجمع كل فريق من الفقه حجده المؤيدة لرأيه سواء بأعتبارها عقودًا أم أحكامًا.

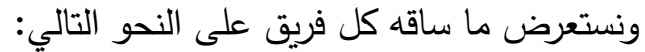
الرأي الأول:- الأحكام الاتفاقية أو الأحكام المثبتة لاتئت لاتفاق الخصوم هي عقود

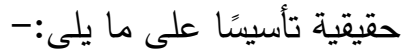

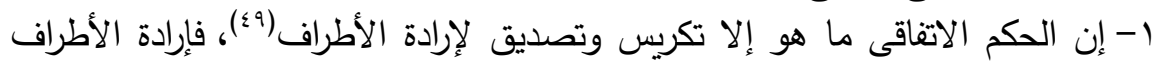

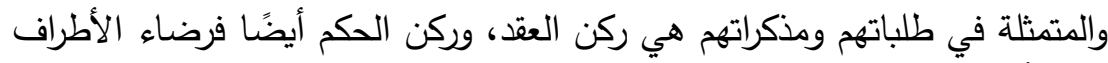

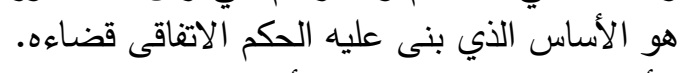

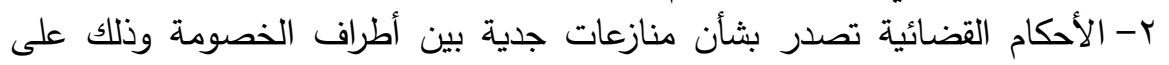

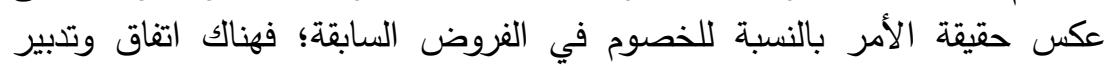

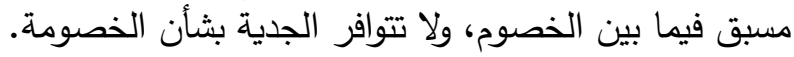

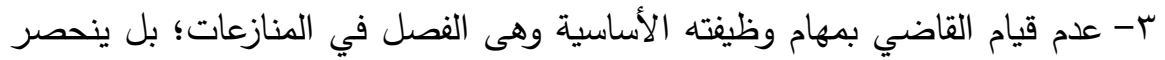

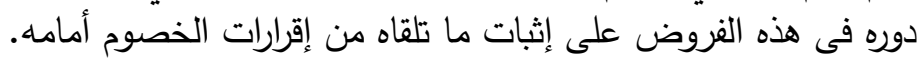

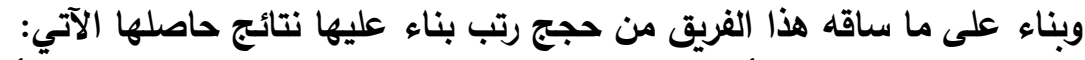

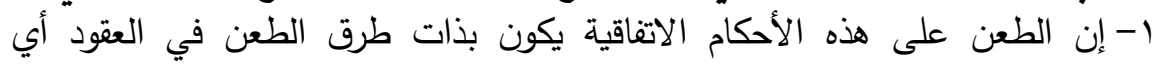

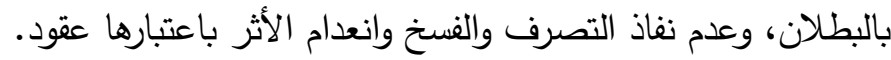

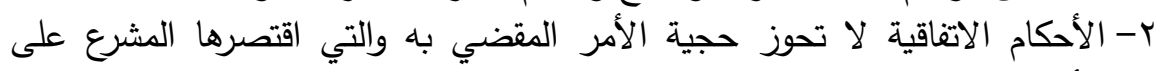
الأحكام القضائية.

r- يلتزم الطرفان بالعقد ولو قبل صدور الحكم ما لم يكن العقد معلقًا على صدور الحكم

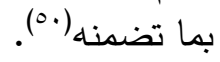
الرأي الثاني: الأحكام الاتفاقية أو الأحكام المثبتة لاتفاق الخصوم هي أحكام قضائية تأسيسًا على ما يلى الئى: 1- عدم تفرقة قانون المرافعات في أحكامه فيما بين الأحكام القضائية ألقائية أو الأحكام

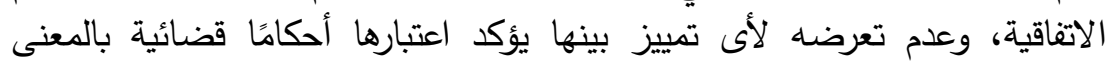
الفني.

(49) MILHAUD, De la simulation dans les actes juridiques, these, Montpellier 1889, op.cit, p. 141 ets.

Cazal (Eugene), Etude Theorique et pratique sur les actes simules, These d'universite de Montpellier, 1879, gustava firmin et Montane, p. 170 ets.

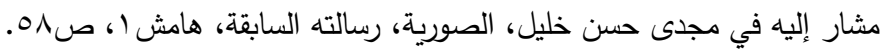

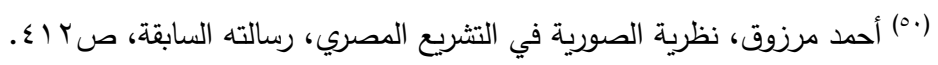


r- إن الأطراف يلجأون إلى القضاء للحصول على حكم ليكسبوا اتفاقاته شكل الأحكام

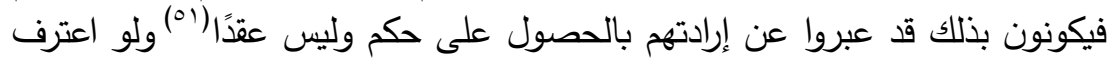

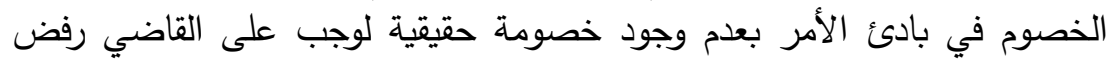

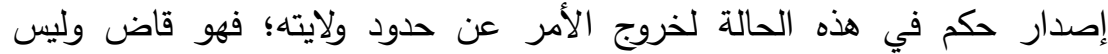
بموثق (or) r- إن التصريح بجوازيه الطعن في الأحكام الاتفاقية بالطرق المقررة نفسها للطعن على حلى الطي

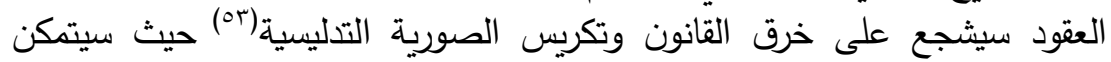

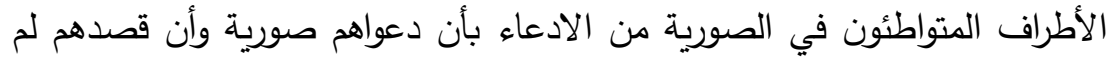

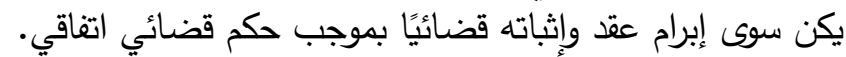

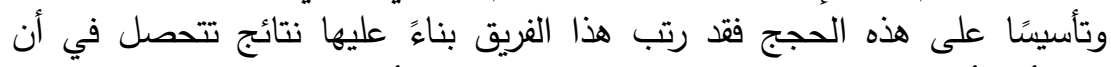

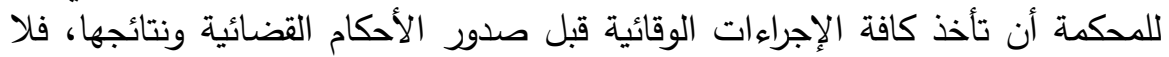

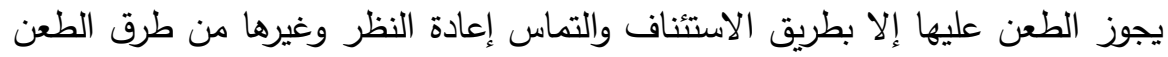

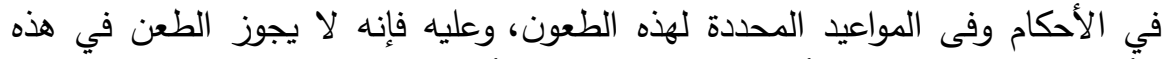

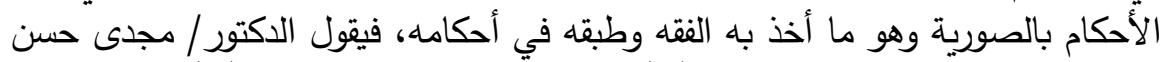

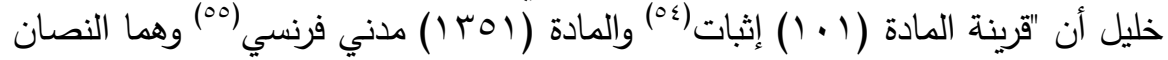

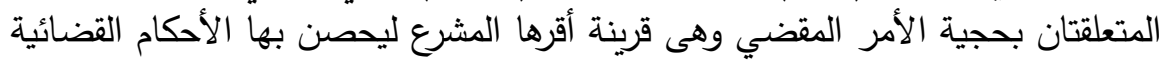

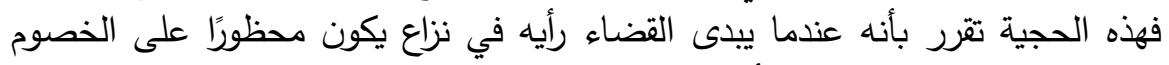

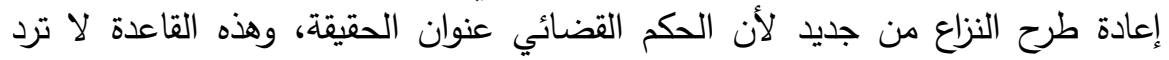

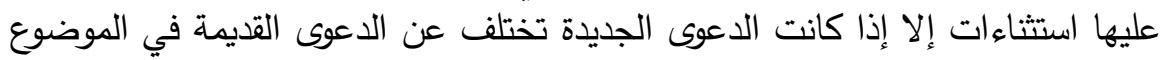

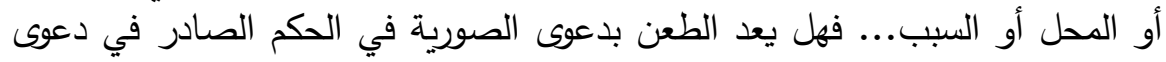

${ }^{(51)}$ Glasson (Paul), "Theorie de la simulation, p.166.

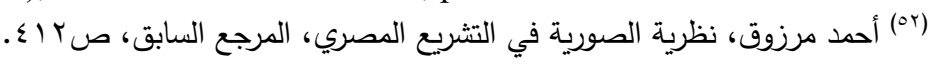

(53) Glasson (Paul), “Theorie de la simulation, op.cit, p. 165 ets.

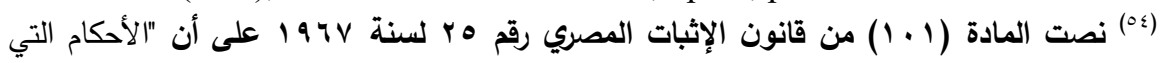

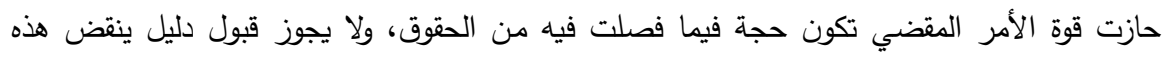

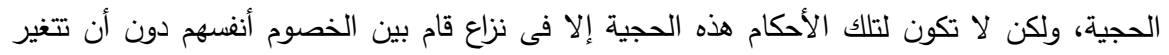

$$
\text { صفاتهم وتتعلق بذات الحق محلاً وسبيًا". }
$$

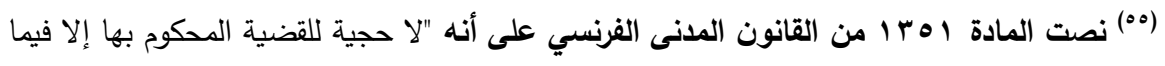

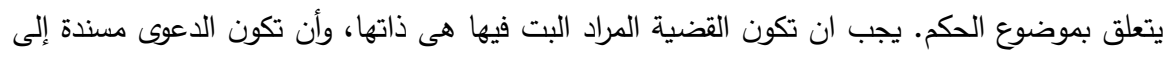
السبب نفسه، وأن تتشكل الخصومة بين الأطراف ذاتها، ومقدمة من قبلهم وضد بعضهم البعض بالصفة البها 


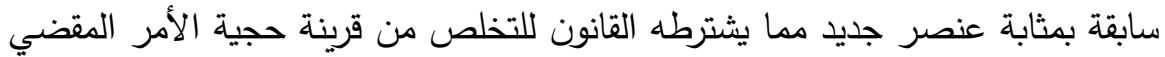

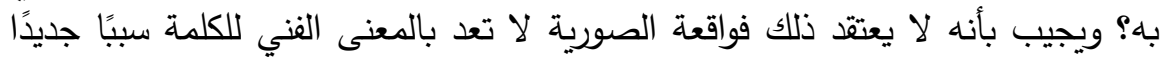

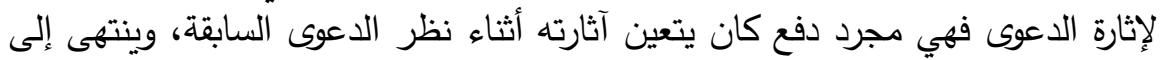

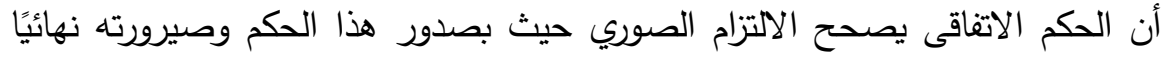

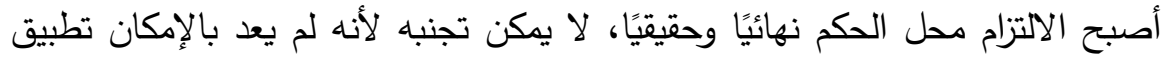

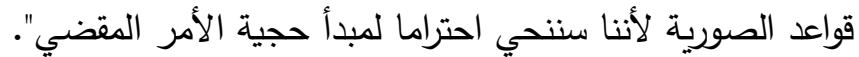

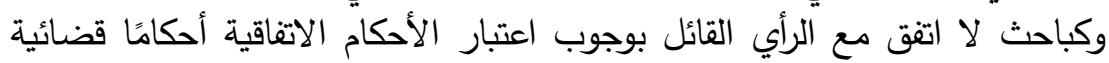

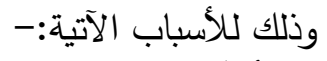

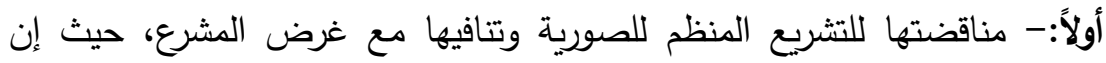

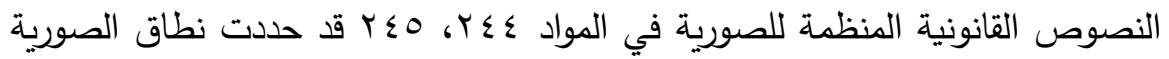

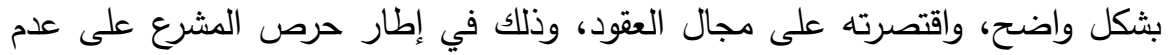

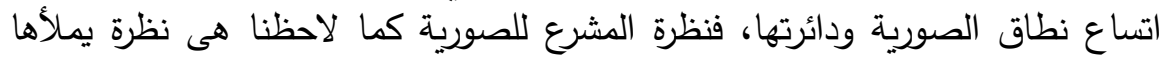

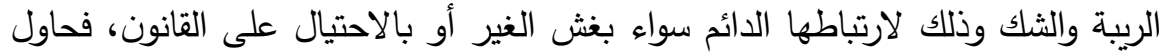

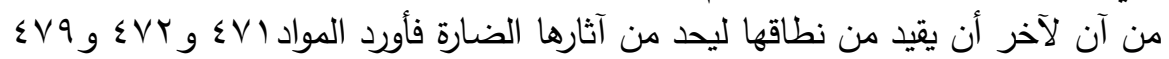

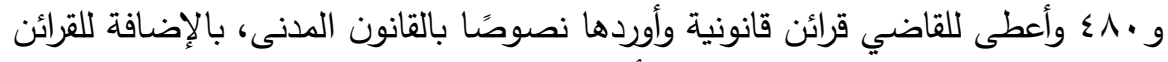

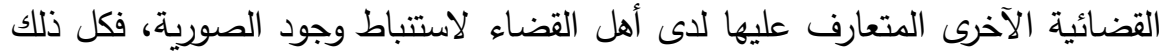

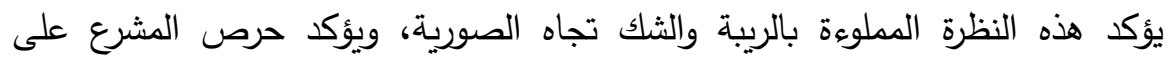

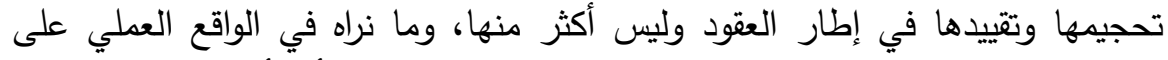

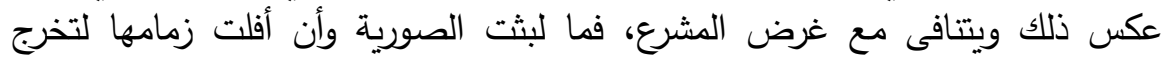

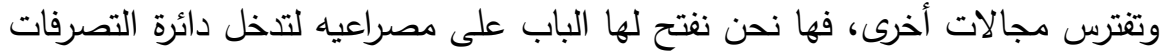

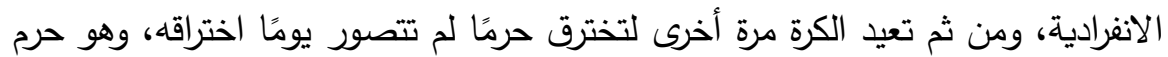

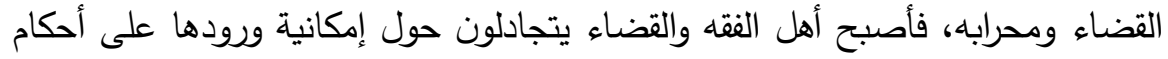

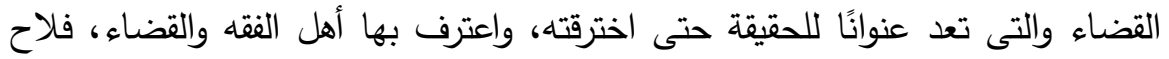
لها في الأفق ثانية أن تعيد الكرة لتصنع ثغرة أخرى لتوسيع نطاقها محاولة إيجاد المساواة التهاة

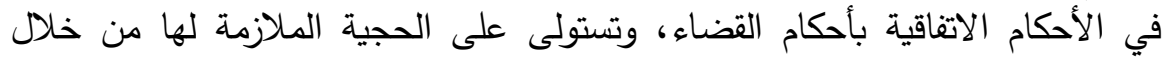

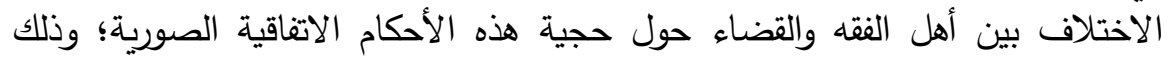

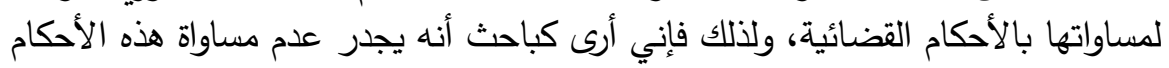

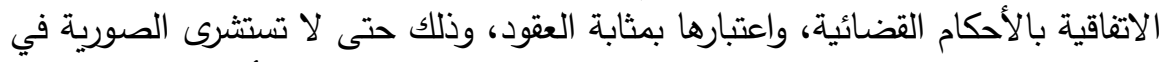

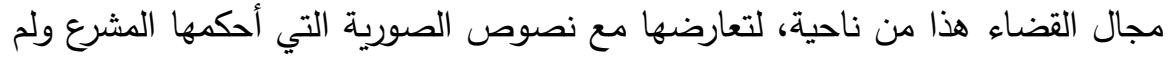

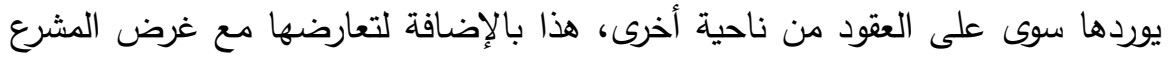


نطاق الصورية

الباحث/ عماد محم حسن القتيشي

ثانيًا:- عدم تأييد المشرع والإجتهاد القضائى لإعتبار بعض الأحكام القضائية

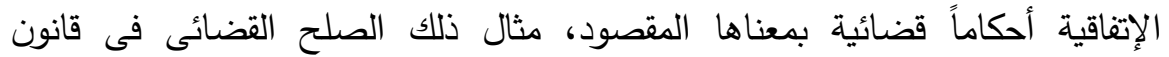

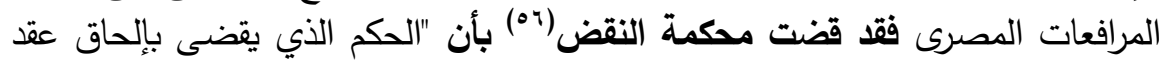

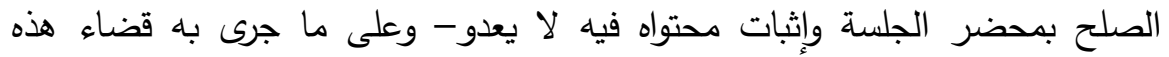
المحكمة- أن يكون عقدًا وليس لله حجية الثيء الثيء المحكوم بهاه، وإن أعطى شكل الأحكام عند إثباته".

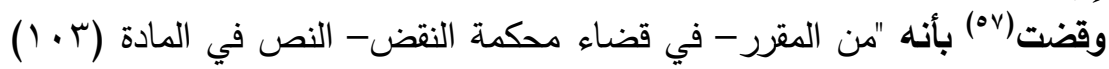

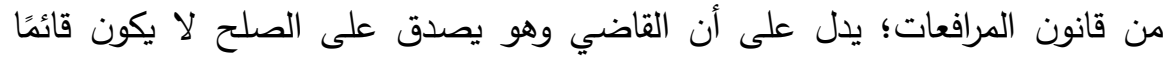

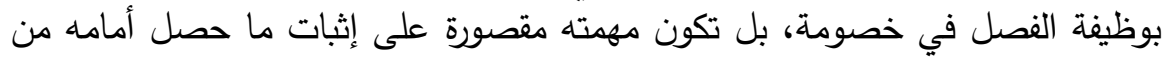

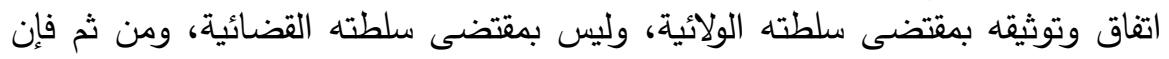
هذا الاتفاق لا يعدو أن يكون عقدًا وليس له حجية الثية ولئه الثيء المحكوم به، وإن أعطى شكل

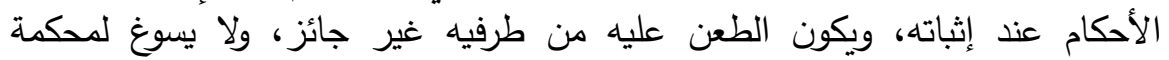

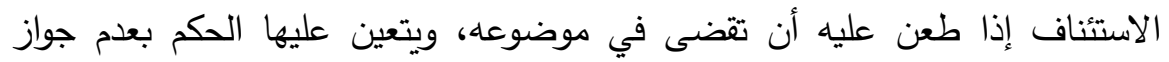

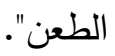

وقضت(^) بأن "العقد الصوري- وعلى ما جرى به قضاء هذه المحكمة- لا وجود

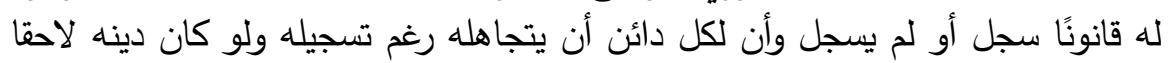

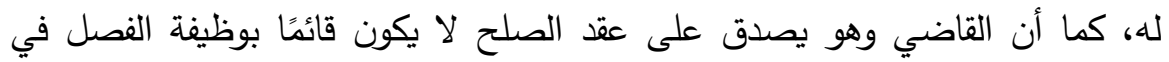

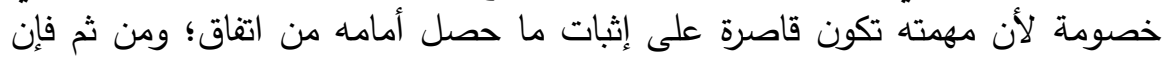

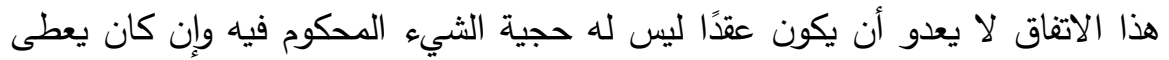

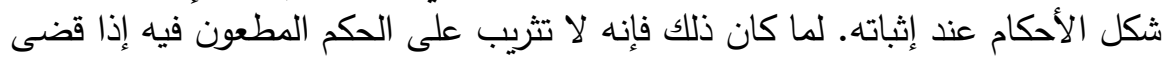

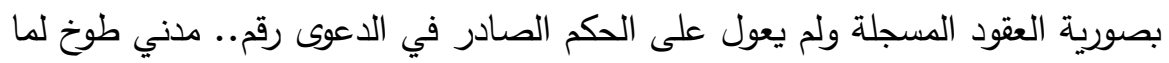
ثبت للمحكمة التي أصدرته بما لها من سلطة تقدير أدلة الدعوى من فن أنها في حقيقتها وصيه ويضحى النعي عليه بهذا السبب من أسباب الطعن على غيل ألى ألى أساس".

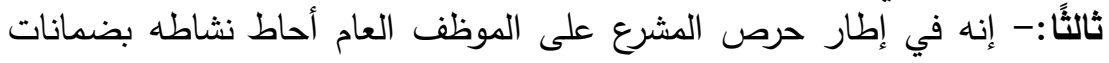

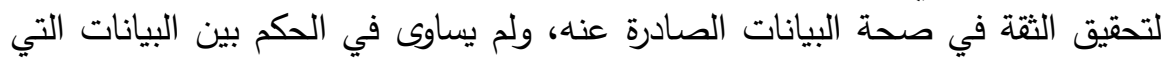

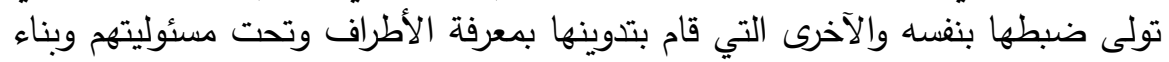

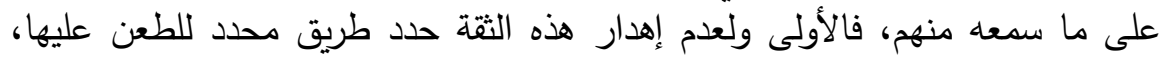
وهو التزوير وأعطى للأطراف حرية الإثبات، كل ذلإنك لعدم إهدار الثقة بهذه البيانات

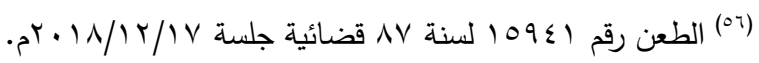

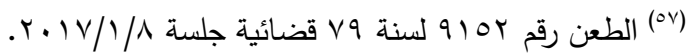

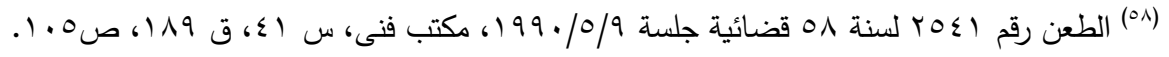

( rvvq) 
المحررة بمعرفة الموثق، أو ليس من الأولى أن نوفر هذه الحماية للأحكام القضائية التي

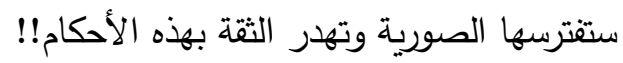
أفبعد أن كان "الحكم عنوان الحقيقة" هل ستصبح لهذه الهذام الأحكام عناوين أخرى،

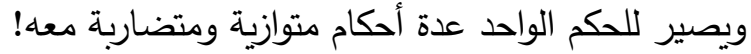

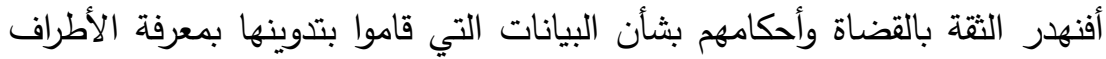

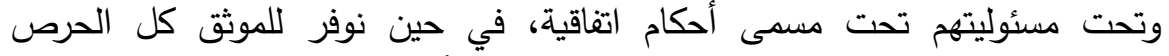

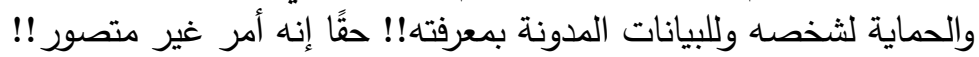

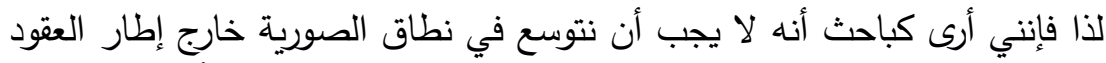

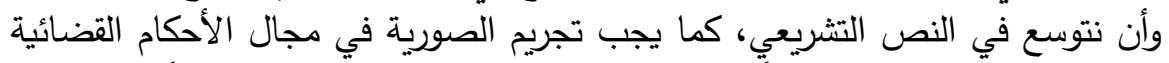

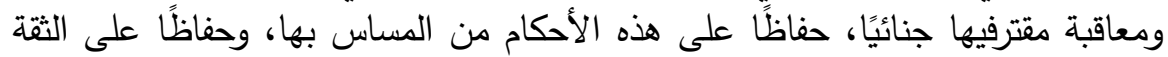

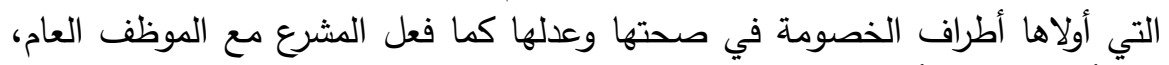

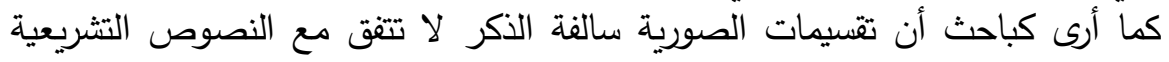
المنظمة للصورية والتى تقتصرها على العقود دون سواها من التصرفات الآخرى.

الخاتمة

ناقشنا فى هذه الرسالة موضوعًا مهمًا من مواضيع القانون المدنى، وهو الصورية

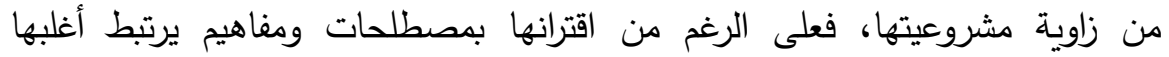

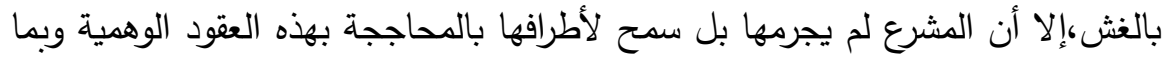

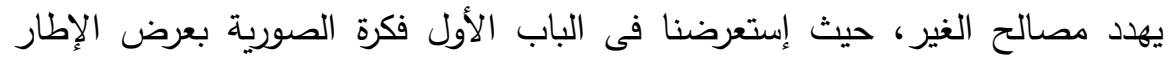

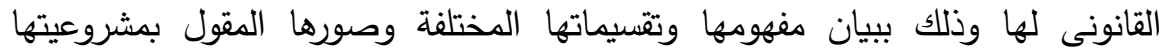

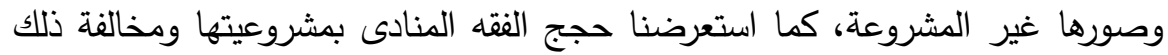

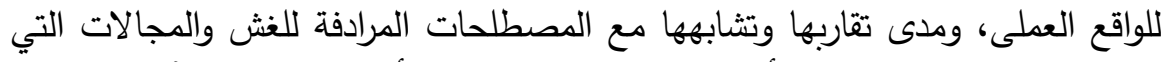

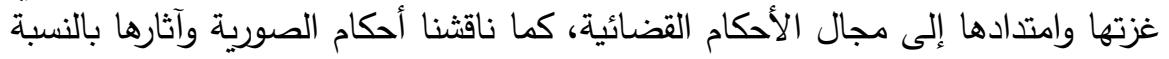

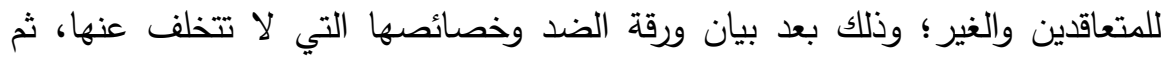

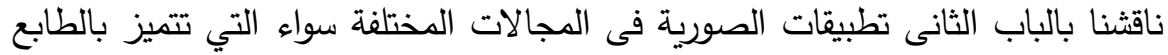

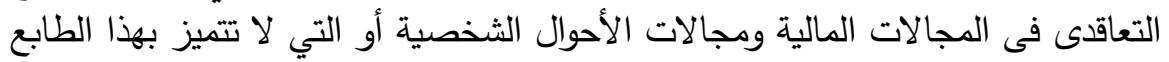

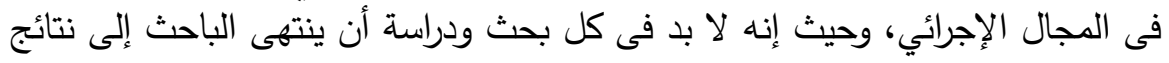

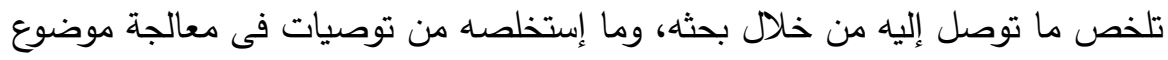

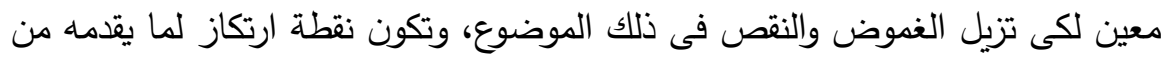

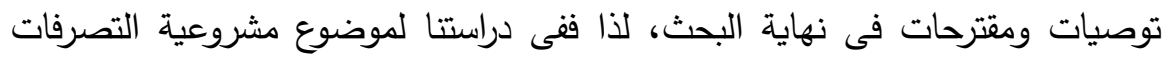

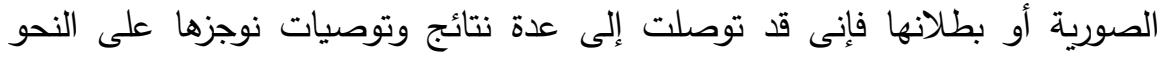


نطاق الصورية

الباحث/ عماد محمد حسن القتيشي

قائمة المراجع

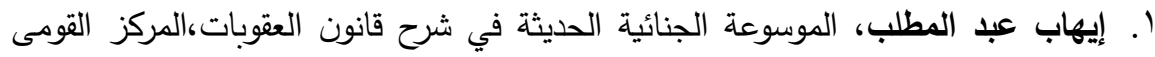

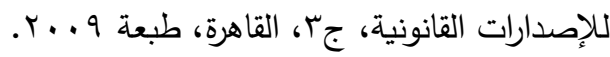

r. أحمد أبو الوفا، التعليق على نصوص قانية جانون الاثبات مقدمة فى علم الاثبات، منشأة

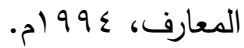

r. أحمد الصادق، التقنين المدنى- شرح أحكام التقنين المدني، جزئيين، دار القانون

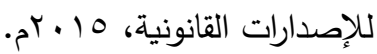

ع. أحمد حشمت أبو ستيت، نظرية الإلتزام في القانون المدنى المصري، مكتبة عبد الله وهبة،

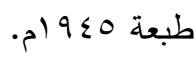

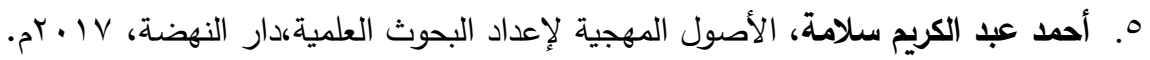

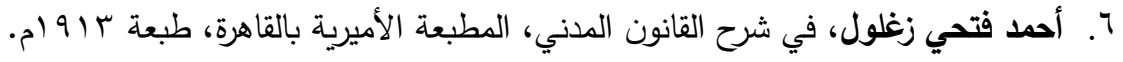

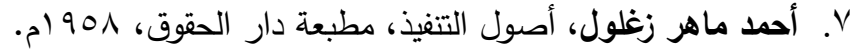

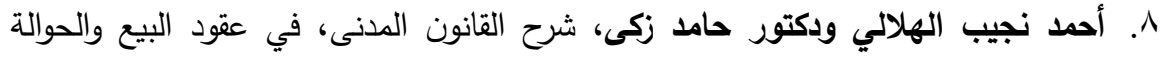
والمقايضة، طبعة 9 و (1م، بدون ذكر دار للنشر .

9 9. أحمد نجيب الهلالي، شرح القانون المدنى في العقود، الجزء الأول، في البيع والحوالة

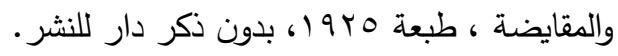

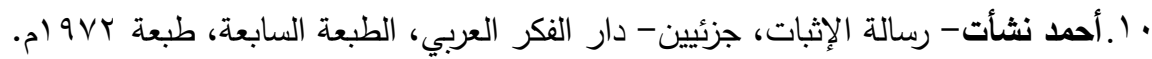

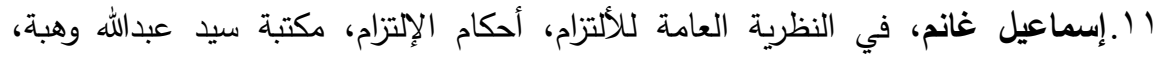

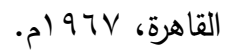

r ا.إسماعيل غانم، مذكرات في الحقوق العينية الأصلية، الجزء الثاني، مكتبة سيد عبدالله وهبة، طبعة 901 ام.

rا.إلياس نصيف، موسوعة العقود المدنية والتجارية، أحكام العقد، الجزء الأول، الطبعة

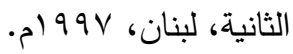

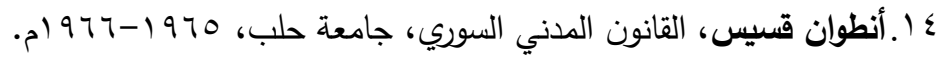

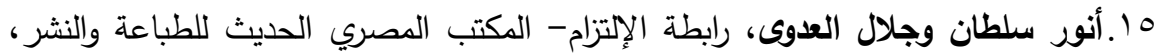
. 971 17 أنور سلطان، النظرية العامة للألتزام ،أحكام الألتزام، دار الجامعة الجديدة، الأسكندرية، .

rVAl 
V ا. أنور سلطان، مصادر الإلتزام في القانون المدني الأردني- دراسة مقارنة بالفقه الإسلامي،

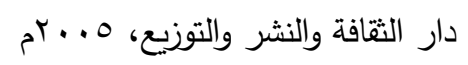

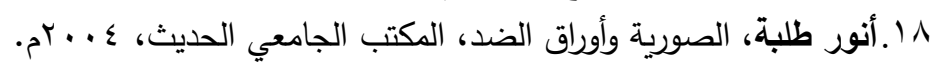

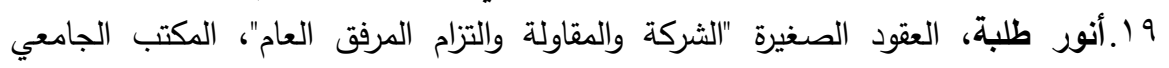

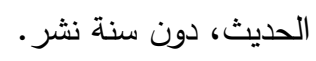

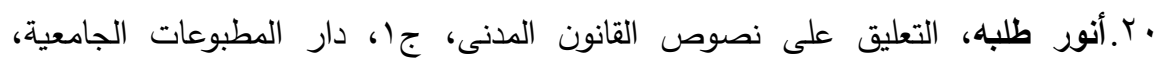

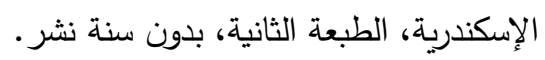

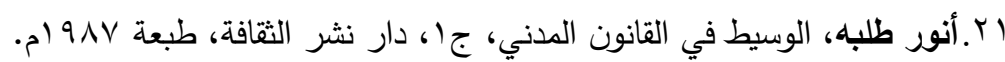

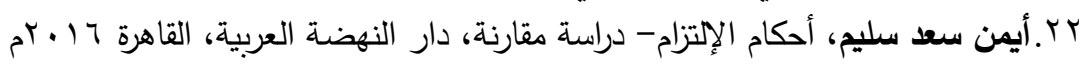

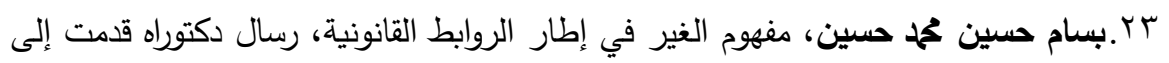

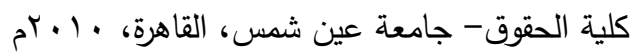

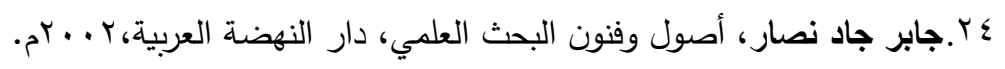

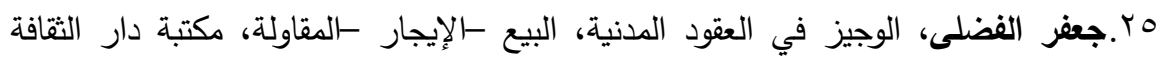

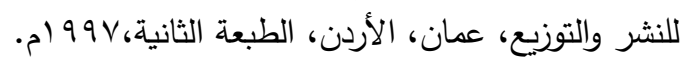

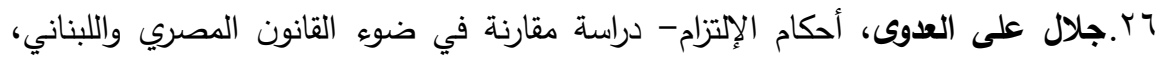

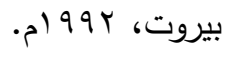

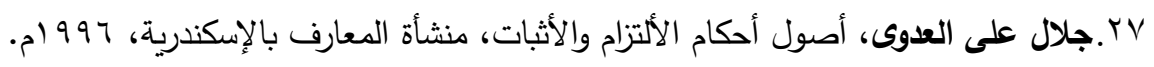

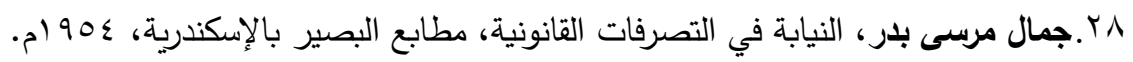

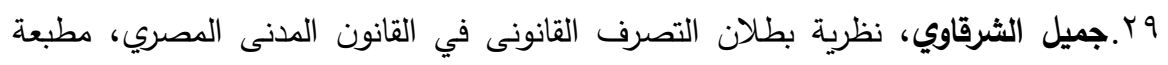

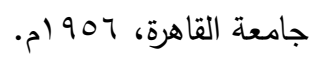

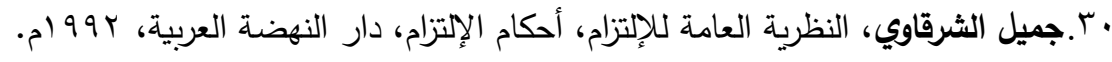

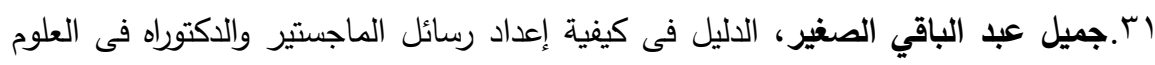

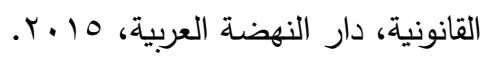

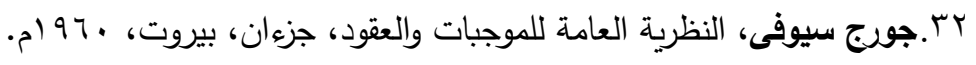

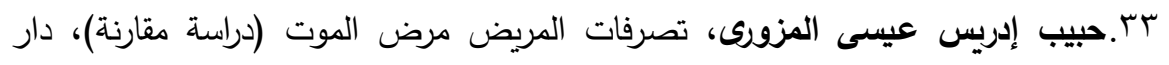

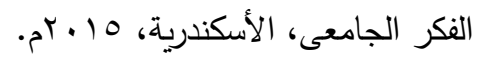

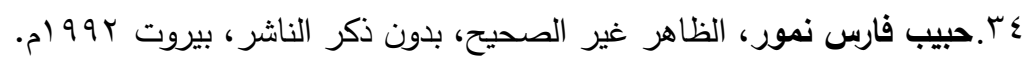

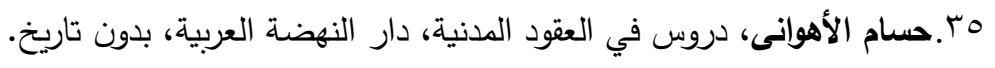

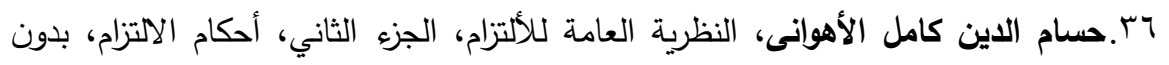

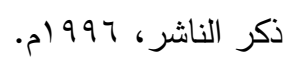

\section{$($ rvir $)$}

